NBER WORKING PAPER SERIES

\title{
BANK DISTRESS DURING THE GREAT CONTRACTION, 1929 TO 1933, NEW DATA FROM THE ARCHIVES OF THE BOARD OF GOVERNORS
}

\author{
Gary Richardson \\ Working Paper 12590 \\ http://www.nber.org/papers/w12590 \\ NATIONAL BUREAU OF ECONOMIC RESEARCH \\ 1050 Massachusetts Avenue \\ Cambridge, MA 02138 \\ October 2006
}

I thank Shagufta Ahmed, Shaista Ahmed, Jacqueline Chattopadhay, Ching-Yi Chung, Nathan Montgomery, Yuiichi Inomata, Mark Ng, Mitra Pai, Doris Sum, Brandon Tsang, Ian Wagner, and Eve Wang for research assistance. I thank Reid Click, Deborah Kauffman, Ed and Edwin Richardson, and Gloria Richardson for accommodations near the National Archives. I thank Erik Heitfield for the loan of photographic equipment. I thank Marigee Bacolod, Dan Bogart, William Branch, Mark Carlson, Milton Friedman, Michelle Garfinkel, Ami Glazer, Joseph Mason, and Kris Mitchener for extensive comments on earlier drafts of this essay. I thank numerous friends and colleagues for comments, advice, and encouragement. The views expressed herein are those of the author(s) and do not necessarily reflect the views of the National Bureau of Economic Research.

(C) 2006 by Gary Richardson. All rights reserved. Short sections of text, not to exceed two paragraphs, may be quoted without explicit permission provided that full credit, including $\bigcirc$ notice, is given to the source. 
Bank Distress During the Great Contraction, 1929 to 1933, New Data from the Archives of the Board of Governors

Gary Richardson

NBER Working Paper No. 12590

October 2006

JEL No. E42,E5,E65,N1,N12

\title{
ABSTRACT
}

During the contraction from 1929 through 1933, the Federal Reserve System tracked changes in the status of all banks operating in the United States and determined the cause of each bank suspension. This essay introduces that hitherto dormant data and analyzes chronological patterns in aggregate series constructed from it. The analysis demonstrates both illiquidity and insolvency were substantial sources of bank distress. Contagion (via correspondent networks and bank runs) propagated the initial banking panics. As the depression deepened and asset values declined, insolvency loomed as the principal threat to depository institutions. These patterns corroborate some and question other conjectures concerning the causes and consequences of the financial crisis during the Great Contraction.

\author{
Gary Richardson \\ Department of Economics \\ University of California, Irvine \\ Irvine, CA 92697-5100 \\ and NBER \\ garyr@uci.edu
}


Miss Jones, Division of Bank Operations, requests that she be notified should any of this data be considered for destruction. She considers this valuable from a historical standpoint as it is the only record the Board has prior to 1933.

Plans are now under way for making a card record, and Miss Jones wants to be sure this record is complete prior to destruction.

Esther Crews

June $11,1941^{1}$

\section{Introduction}

The causes, consequences, and possibilities of preventing the banking panics of the Great Depression have been debated for seven decades. The debate's factual foundations rest upon data published in the Federal Reserve Bulletin. The September 1937 issue contains the only comprehensive collection of statistics on suspended banks, and is the sole source of aggregate bank failure rates (Board of Governors 1937, hereafter FRB’37). ${ }^{2}$ Scholars studying the contraction continuously redefine, reinterpret, and reveal new relationships between data from FRB'37 and measures of industrial, commercial, and financial activity.

The principal reason the debate continues may be the single source of evidence. FRB'37 provides imperfect information about bank distress. It distinguishes neither temporary from terminal suspensions, nor voluntary from involuntary liquidations, nor institutions afflicted by illiquidity from banks suffering insolvency. It contains information neither on the causes of bank suspensions nor the number of bank mergers. The smallest period of aggregation at the national level is the

\footnotetext{
1 Memo in the first file in the first box of St. 6386 forms in the National Archives. The card record, a compact method of recording information compatible with tabulating machines and suitable for long term storage, was never completed. Plans called for cards to describe each bank suspension, liquidation, merger, reopening, and other change of status (e.g. withdrawal from Federal Reserve membership) which occurred in the United States between 1929 and 1933. Cards would also report the cause of each suspension and describe each consolidation due to financial difficulties. Work had barely begun when the Japanese bombed Pearl Harbor. The Federal Reserve prioritized wartime tasks. Historical studies were forsaken. The Division of Bank Operations cleared its decks by sending records from the previous decade to the Board's Central Subject File, including those related to the Division's inchoate endeavor to encode data from the 1930s. The Division never returned to the task.

2 Reprints of these series (or cross-tabulations based upon them) appeared in Banking and Monetary Statistics (Board of Governors 1943) and Historical Statistics of the United States (Bureau of Census 1975). Precursors to these series (cont.)
} 
month and at the Federal Reserve district level is the year. Key terms remain undefined, leaving much open to interpretation.

This essay introduces new statistical series that provide precise, detailed, aggregate information about categories of bank distress and causes of bank suspensions. The source for the new series is the same as for the old series. From 1929 though 1933, the Board of Governors collected data on changes of status for all banks operating in the United States, both members of the Federal Reserve System and nonmembers, state and national, incorporated and private. The Board also analyzed the cause of each bank suspension. The Division of Bank Operations recorded this information on the St. 6386 series of forms. The series comprehensively covered the commercial banking industry from January 1929 through the national banking holiday in March 1933. Observations existed for every event affecting every bank. These events included the major, such as openings, closings, reopenings, receiverships, and consolidations, and the minor, such as changes in Federal Reserve membership, capital stock, charter type, and even street address. The forms also included financial information for each bank on the date of each transaction. The complete series of St. 6386 forms survives in the National Archives of the United States. ${ }^{3}$

Since the St. 6386 database covers the entire population of banks and events, analysis of it may be conducted in a manner more straightforward than in the current literature. Currently, scholars employ the FRB’37 series, samples of microdata from various sources, economic logic, and statistical techniques to infer patterns of events. The debate revolves around and conclusions depend upon the assumptions underlying the analysis. Now, there is no need to argue over the

appeared in various publications of the Board of Governors and in Bank Suspension in the United States (Goldenweiser et. al. 1931). Studies of the banking panics published prior to 1938 employ these predecessor series.

3 The St. 6386 forms were the basis of the Federal Reserve's bank data collection system from 1929 to 1933 . All facts and figures about bank distress published by the Board of Governors or the Federal Reserve district banks and much of the material published by state banking authorities originated with this source. 
nature and timing of events. The St. 6386 database reveals what happened to every bank in the nation on every day of the contraction.

This essay analyzes aggregate series derived from the database using non-parametric methods. The goal is filter the data as little as possible, allowing the evidence - and the hundreds of bank examiners, accountants, receivers, economists, Federal Reserve agents, and others who collaboratively created this data set - to speak for itself. Summary statistics, charts, and graphs demonstrate that some types of bank distress were less prevalent than the conventional wisdom claims; other types of bank distress, such as temporary banks suspensions, contagion through correspondent networks, and suspensions due to illiquid assets, which according to the conventional wisdom seldom occurred, in fact occurred often and played a pivotal role in the collapse of the banking system. ${ }^{4}$

This direct examination of the definitive data for the entire population of banks and events answers two fundamental questions about the contraction. When did banks fail? Why did banks fail? An accurate answer to the latter must be extended, because the nature of the banking crisis changed over time. Before October 1930, the pattern of failures resembled the pattern that prevailed during the 1920s. Small, rural banks with large loan losses failed at a steady rate. In November 1930, the collapse of correspondent networks triggered banking panics. Runs rose in number and severity after prominent financial conglomerates in New York and Los Angeles closed amid scandals covered prominently in the national press. More than a third of the banks which closed their doors to depositors soon resumed normal operations. Following Britain’s departure from the gold standard in September 1931, the depression deepened. Asset values declined. Insolvency

4 For example, while Milton Friedman and Anna Schwartz (1963) and Ben Bernanke (1983, pp. 259-260) argue that during the Depression, banks did not suspend the conversion of deposits to currency as they had done during banking crises before the creation of the Federal Reserve System. The data introduced in this essay demonstrates otherwise. 
loomed as the largest threat facing depository institutions. During the financial crisis in the winter of 1933, almost all of the banks that failed were liquidated at a substantial loss.

Overall, between the Great Crash and the Banking Holiday, both illiquidity and insolvency were substantial sources of bank distress. Nearly three fourths of the banks that closed their doors due to financial difficulties were insolvent. Slightly more than one quarter were solvent, and without outside financial assistance, reopened for business, or repaid all of their depositors and creditors, or merged at face value with other institutions. Frozen and devalued assets were a primary cause of approximately one half of all bank suspensions and a contributing cause of another one quarter. Heavy withdrawals were a primary cause of nearly one half of all bank suspensions and a contributing cause of another one sixth.

The rest of this essay substantiates this depiction of the banking crises of the Great Contraction. Section 1 reviews the relevant literature, highlights FRB'37's role in academic debates, and elucidates the utility of the new evidence. Section 2 describes the data, defines key concepts, and compares the archival evidence to the old FRB'37 series. An appendix presents facsimiles of the St. 6386 forms and discusses issues important for interpreting empirical work based upon this new and unique source. Section 3 presents chronological patterns for the four categories of bank distress: terminal suspensions, temporary suspensions, consolidations due to financial difficulties, and voluntary liquidations. Section 4 presents chronological patterns for the principal causes of bank suspensions: heavy withdrawals, problematic assets, the closure of correspondent banks, defalcations, and mismanagement. Section 5 discusses the implications these chronological patterns, which corroborate some conjectures, cast doubt on others, and raise new questions concerning the causes and consequences of the collapse of the banking system during the Great Depression. 


\section{Review of the Literature}

Scholars ask three big questions about the banking system during the Great Depression. Why did bank suspensions surge at certain points in time? How did bank suspensions affect commercial and industrial activity? Could Federal Reserve intervention have prevented (or did its actions trigger) this crisis? Despite 70 years of analysis, debate persists about the answer to each inquiry.

Concerning causes of the banking crises, some scholars conclude that banks failed because the economy contracted. Loan default rates rose. Asset values declined. Deteriorating fundamentals forced banks into insolvency, continuing a process of liquidation that began during the 1920s. ${ }^{5}$ Other scholars conclude that a contagion of fear, a flight to cash holdings, and withdrawals en masse drained deposits from banks and pushed financial markets towards collapse. Illiquidity of assets and Federal Reserve inaction exacerbated the credit crunch. ${ }^{6}$

Concerning the consequences of the banking crises, some scholars see bank failures as symptoms of ongoing events with no special role in the propagation of the downturn. ${ }^{7}$ Other scholars believe that banking panics had monetary effects. Panics eroded depositors’ confidence, induced further withdrawals, forced banks to liquidate assets at deep discounts, lowered asset prices, encouraged banks to hold excess reserves, and reduced the money multiplier. This vicious

5 Peter Temin (1976) argue that real, rather than monetary, forces caused banks to fail and the economy to contract by regressing state-level FRB'37 suspension data on various explanatory variables. Charles Calomiris and Joseph Mason (2003) support the supposition that contagion forced banks to fail by regressing time-to-liquidation for individual Fed member banks on an array of bank characteristics, aggregate variables, and state-level FRB'37 suspension rates. Eugene N. White (1984) initiated the use of bank balance sheet data to analyze these issues.

6 Milton Friedman and Anna Schwartz (1963) argue that the Federal Reserves' failure to act as a lender of last resort, prevent banking panics, and stem the decline of the money supply transmogrified what would have been an ordinary recession into the Great Depression by examining seasonally-adjusted series of deposits in suspended banks from FRB'37 to determine the dates of banking panics and correlating those dates with changes in monetary aggregates. Elmus Wicker (1996) uses district-level data on suspensions from FRB'37 to illuminate the regional patterns of panics.

7 This view arises from Keynesian, classical, real business cycle, and other macroeconomic models. Temin's spending hypothesis (Temin 1976) is the seminal statement of the stark Keynesian conception of the contraction, which sees (cont.) 
cycle reduced the money supply and turned what would have been a typical recession into a cataclysmic contraction. ${ }^{8}$ Another set of scholars maintains that bank panics influenced economic activity by disrupting financial intermediation. Bank failures increased the cost of credit intermediation, dislocated the financing of small and medium firms, disrupted current production, and curtailed investment spending. This financial acceleration deepened the depression. ${ }^{9}$

Concerning the possibilities of preventing the banking panics, some scholars argue the Federal Reserve could have done little to aid ailing banks. Fundamental forces pushed banks into insolvency; monetary intervention could not pull them out. Liquidity assistance could not eliminate loan losses. Open-market expansion - even on a massive scale - could not lift the economy out of the liquidity trap (Temin 1976). Other scholars argue that the Federal Reserve could not aid ailing banks directly, since illiquidity and contagion caused few banks failures, but that massive openmarket expansions, such as those that the Roosevelt administration implemented after abandoning the gold standard, could reignite economic progress, and thus indirectly alleviate the banking situation (Calomiris and Mason 2003, Eichengreen 1992, Romer 1992, Temin 1989). Another set of scholars argue that even limited assistance from the Federal Reserve might have mitigated banking panics. By acting as a lender of last resort and extending loans to solvent but illiquid institutions, the Federal Reserve could have kept ailing institutions afloat. A credible commitment to do so might have calmed consumers, reassured bankers, raised the money multiplier, alleviated the credit crunch, and eased the economic situation (Richardson and Troost 2005). A final and influential set of scholars concludes that the Federal Reserve's sins were of commission as well as omission. The

bank failures as a symptom of the autonomous decline in consumption and investment expenditure, and which dates back at least to the publication of Keynes' General Theory.

8 Friedman and Schwartz (1963) contains the seminal statement of the monetarist position, whose roots date back at least to the publications of Lauchlin Curry (1931 and 1932) and the Chicago monetary tradition which arose at that time. 
Federal Reserve not only neglected to aid ailing banks, but by raising interest rates, reducing the monetary base, and restricting discount lending, the Federal Reserve weakened all banks, and created conditions conducive to panics. As evidence, these scholars highlight the Federal Reserve's monetary contraction in 1928 and the Federal Reserve’s defense of the gold standard in 1931 (Friedman and Schwartz 1963, Meltzer 2003).

Much of the academic debate focuses on competing interpretations of the Depression's initial banking crisis in the fall of 1930. According to Friedman and Schwartz (1963), the crisis began when “a contagion of fear spread among depositors (Friedman and Schwartz 1963, p. 308).” The contagion began in agricultural areas and accelerated after the failure of the Bank of the United States, which was the largest commercial bank ever to have failed up to that time in U.S. history, and whose distinctive name "led many at home and abroad to regard it somehow as an official bank (Friedman and Schwartz 1963, pp. 309-11).” The panic spread more rapidly than it would have under the pre-Federal Reserve banking system, because the existence of the Federal Reserve prevented banks from restricting the conversion of deposits into currency, which would have cut the “vicious circle set in train by the search for liquidity.” Such a restriction would almost certainly have prevented the subsequent waves of bank failures that were destined to come in 1931, 1932, and 1933, just as restriction in 1893 and 1907 had quickly ended bank suspension arising primarily from lack of liquidity (Friedman and Schwartz 1963, p. 311).”

According to Wicker $(1980,1996)$, the collapse of Caldwell and Company triggered the crisis. Caldwell controlled one of the largest banking chains in the South, with assets over $\$ 200,000,000$, and one of the largest insurance groups in the region, with assets over \$230,000.000.

9 Ben Bernanke (1982) regresses growth rates of industrial production on first differences of deposits in suspended banks to show that suspensions increased the cost of credit intermediation 
Questionable managerial and financial practices caused the firm's demise, which quickly forced the suspension of the Bank of Tennessee and its affiliates.

According to Temin and White, the first banking crisis was caused by worsening fundamental factors, rather than contagion among banks. Temin (1976) argues that the Stock Market Crash, the Dust Bowl, and the ensuing financial, agricultural, and industrial depressions reduced the value of bank's investments and raised suspension rates. White argues that the bank failures during 1930 “did not mark a departure from previous experience (White 1984, p. 135).” Both real and monetary factors played a part. Poorly performing assets and restrictive monetary policy were both contributing factors. The former pushed banks towards insolvency. The latter raised banks' costs by forcing them to seek costly sources of funds such as bills payable, acceptances, and rediscounts. Since banks failed for those reasons throughout the 1920s and since national "bank failures can be predicted a year in advance with some accuracy (White 1984, p. 135),” the banking failures during the fall of 1930 appear to be an accentuation of prior trends, rather than a turning point in the propagation of the Great Depression. ${ }^{10}$

The data introduced by this essay demonstrates that all of these views have merit. Each portrays a portion of a complex, dynamic mosaic. Conclusions which rely solely upon FRB'37 differ because the data are open to interpretation. Conclusions based upon panels of microdata differ because the samples depict certain types of events (such as liquidations) affecting certain banks (such as national banks) in particular times and places. Reconciling these views requires comprehensive, definitive data. The remainder of this essay turns to that task.

10 White (1984) pioneered efforts to examine samples of data from national banks. Subsequent work examines banks within individual cities, states, and Federal Reserve districts (Charles Calomris and Joseph Mason 1997, Mark Carlson 2004). The most recent and comprehensive work (Calomiris and Mason 2003), which analyzes a panel of all Federal Reserve member banks, yields a strong and stark conclusion. The "two Friedman-Schwartz crises are not associated with positive unexplained residual failure risk, or increased importance of bank illiquidity for forecasting failure (2003).” 


\section{2: Data Definitions, Quality, and Comparisons}

During the 1920s, the Federal Reserve Board of Governors developed a lexicon for discussing bank distress and procedures for collecting data on the phenomenon. An appendix delves into details of the definitions and the collection process. This section concisely characterizes the key concepts before comparing the archival evidence to previously published tabulations. The comparison demonstrates two important points. First, the archives retain the original data set in its entirety. Second, the archival evidence contains information previously unavailable to scholars.

In the Federal Reserve's lexicon, a suspension was a bank that closed its doors to depositors and ceased conducting normal banking business for at least one business day. Some, but not all, suspended banks reopened for business. A liquidation was a permanent suspension. A liquidating bank closed its doors to the public, surrendered its charter, and repaid depositors, usually under the auspices of a court appointed officer known as a receiver. A voluntary liquidation was a category of closure in which banks ceased operations and rapidly arranged to repay depositors the full value of their deposits. Voluntary liquidations did not require the services of receivers and were not classified as suspensions. A consolidation (or merger) was the corporate union of two or more banks into one bank which continued operations as a single business entity and under a single charter. The categories of bank distress were typically construed to be temporary suspensions, terminal suspensions (i.e. liquidations), voluntary liquidations, and consolidations due to financial difficulties. $^{11}$

The Federal Reserve attributed most bank suspensions to one of five common causes. The first was slow, doubtful, or worthless paper. The term worthless paper indicated an asset with little or no value. The term doubtful paper meant an asset unlikely to yield book value. The term slow 
paper meant an asset likely to yield full value in time, but whose repayment lagged or which could not be converted to full cash value at short notice. The second common cause of suspension was heavy withdrawals, the typical example being a bank run. The third was failure a banking correspondent. Correspondents were banks with ongoing relationships facilitated by deposits of funds. A typical example is a county bank (the client) which kept its reserve deposits within and cleared its checks through a national bank in a reserve city (the correspondent). The fourth common cause was mismanagement. The fifth was defalcation, a monetary deficiency in the accounts of a bank due to fraud or breach of trust.

The first question one should ask about the archival evidence is: do figures from it correspond closely to the figures published in the FRB'37? Figure 1 answers that question. The solid line is the number of bank suspensions each month according to FRB'37. This tally includes all banks: national, state, and private. The dotted line represents the archival data. It is calculated from the St. 6386 forms in the National Archives using the definitions, rules, and algorithms established by the Division of Bank Operations in the 1930s. The lines correspond closely. Similar exercises on various cross-tabulations duplicate the analogous series published in 1937. The replication of the FRB'37 series demonstrates that the archival data remains comprehensive. The dataset contains observations for all banks that suspended operations during the Great Depression. ${ }^{12}$

Figure 2 summarizes the new information in the archival data. The entire shaded area indicates the total number of bank changes due to financial difficulties that occurred each week from January 1929 through December 1933. The lower, darkly shaded area indicates the number of

11 Contemporary publications often employed the terms failure and closure as synonyms, which typically (but not universally) referred to the sum of temporary and terminal suspensions.

12 Additional confirmation of this comes from the state-level databases which I have constructed by combining information from government (state examiners, Fed, and OCC reports) and commercial sources (Rand McNally's Bankers Directory and Polk’s Bankers Encyclopedia). For the four states which I have completed, FL, MS, NY, TN, the state-level databases and St. 6386 series of forms match at rates over 99.5\%. 
new observations (i.e. temporary suspensions, voluntary liquidations, and consolidations due to financial difficulties) contained in the archival data. The upper, lightly shaded area indicates the number of terminal suspensions. For each of these observations, the archival evidence adds an array of information including the cause of the suspension, the date of the suspension, the financial condition of the bank on that date, the identity of the institution or individuals who initiated the change, and in many cases, written comments concerning the circumstances leading to and/or resulting from the event.

Three patterns in the new data should be noted. First, the new observations are clustered between the fall of 1930 and winter of 1933, when bank suspensions surged above pre-depression levels in repeated waves of bank failures. Second, the archival evidence allows us to view the data without chronological aggregation. Weekly and daily series of suspensions display volatility much greater than the monthly series published in FRB'37. On several occasions, the number of bank suspensions rose (or fell) overnight by a factor of 20 or more. Such wild swings may be one reason that banking crises made such an impression on the public. Third, the banking holiday of March 1933 does not appear in the archival evidence. Why not? The Federal Reserve’s reporting system was not designed to (and for that reason did not) track the status of banks that closed during state or national banking holidays. The Division of Bank Operations provided a rough approximation (4000) of the number of banks that did not reopen within 3 months of the national banking holiday, which was published (with caveats) in FRB’37. The actual number is unknown. The number was not based on an exact count or hard evidence. The appendix discusses this and other issue in more detail. The following sections of this essay examine chronological patterns in the archival data. 


\section{3: Categories of Bank Distress}

This section examines chronological patterns on categories of bank distress. Table 1 presents annual data. Several patterns appear prominent. The majority of bank changes due to financial distress were terminal suspensions (72.9\%). The remaining changes were divided between temporary suspensions (12.3\%), consolidations due to financial difficulties (9.7\%), and voluntary liquidations (5.2\%). Temporary suspensions occurred at a higher rate early in the depression, when more than one in five suspended banks reopened for business, and usually occurred during surges of bank suspensions which contemporary observers classified as banking panics. Consolidations due to financial difficulties followed a different pattern. Struggling banks were least likely to merge in 1930 and most likely to do so in 1931. The rate of voluntary liquidations followed no discernible trend.

Figure 3 displays patterns of terminal and temporary suspensions from January 1929 to March 1933. The rates of both types of suspensions remained near pre-depression levels until November 1930, when the rates rose to levels unseen since the turn of the century. The rise in temporary suspensions was particularly pronounced. Few temporary suspensions occurred during typical weeks; many weeks witnessed none. Almost all temporary suspensions occurred during waves of bank failures such as the banking crisis of fall 1930, when more than $40 \%$ of all institutions which closed their doors to depositors soon reopened for business. The percentage fell as the depression progressed. Less than $20 \%$ of the banks which closed their doors during the fall of 1931 later reopened. Only a small fraction of the banks which suspended operations during 1932 and 1933 reopened, and most of those that did manage to resume operations did so after receiving infusions of cash from stockholders, depositors, and other sources.

Figure 4 displays patterns of voluntary liquidations and consolidations due to financial difficulties. Kernel-smoothing illuminates trends over time. Consolidations rose during the waves of 
bank failures and peaked at the end of 1932. Voluntary liquidations varied greatly from week to week, and no trend is discernible.

Figure 5 indicates rates at which banks departed from the banking business each year. The horizontal axis divides the rates into solvencies and insolvencies. The share of solvent departures appears above the axis. The numerator of this ratio consists of banks in each year which (i) voluntarily liquidated and (ii) consolidated due to financial difficulties (dark grey area) plus (iii) the number of bank mergers of banks not in financial distress (light grey). The number of mergers is a lower-bound approximation based on the number of 'net changes for other reasons' indicated in Table $3 .^{13}$ The denominator is the number of banks in operation at the beginning of each year. The share of insolvent departures appears below the axis. The numerator is the number of terminal suspensions. The denominator is the number of banks in operation at the beginning of each year. The values for 1933 include banks which ceased operations in January, February, and March with the exception of those closed due to banking holidays declared by state and federal governments. The dotted outlines indicate the annualized rate of departure during the first three months of 1933, or in other words, what would have happened had departure rate during the first quarter continued throughout the year. The last column indicates the rates of departure averaged over the entire contraction.

Figure 5 shows that for the period January 1929 through March 1933, departures from the banking business were split about evenly between solvent and insolvent. Solvent departures principally mergers but also voluntary liquidations and consolidations under duress - were concentrated during the first two years of the contraction (i.e. 1929 and 1930) and during the first half of 1932, a period during which the Federal Reserve System pursued an expansionary policy. 
Insolvent departures gradually increased during 1930 and peaked in 1931 following Britain’s departure from the gold standard, to which the Federal Reserve reacted by raising the discount rate and contracting the money supply. Insolvent departures continued at a high rate in 1932 and spiked upwards during the months before the Roosevelt administration declared a national banking holiday in March 1933.

Together, Figures 3 through 5 demonstrate that during the depression, bank distress occurred in many forms. Some forms for which data has been available - such as the liquidation of insolvent banks - have been studied extensively. Other forms for which data has not been extant - such as temporary suspensions and consolidations due to financial difficulties - have not been analyzed. The hitherto unobserved forms of distress were concentrated during surges of bank suspensions which contemporaries characterized as panics. The concentration suggests that the causes of suspensions during panics differed from the causes during ordinary times. The next section, which examines evidence on the causes of bank suspensions, strengthens that supposition.

\section{4: Causes of Bank Suspensions}

The previous section documented when and how banks departed from the banking business. This section determines why banks did so by analyzing chronological patterns in the causes of bank suspensions. The appendix contains an extensive discussion of how the Board of Governors determined the cause of each bank's demise. The method involved gathering financial data for each institution; talking with the regulators, examiners, receivers, correspondents, and bankers who knew the facts of the issue at hand; applying a set of algorithms devised to determine the cause of the failure; and reporting the results in a lexicon devised to convey the conclusions clearly, concisely,

13 The estimate of mergers used here is a lower bound, since 'net changes for other reasons' equals 'mergers' minus 'new bank openings.' A subsequent essay will provide precise figures after research assistants complete the coding of the remaining microdata, which will take approximately 1 year. 
and consistently. I report these conclusions both in the lexicon employed by economists in the 1920s and after translating them into terms used by modern economists. I should emphasize that I make no judgments about the reasons why particular banks failed. Those judgments were made by contemporary experts possessing far more information about each event than is available to scholars today.

A series of tables and figures present the key findings. Table 2 presents annual figures. Tables 3 presents hazard rates for causes and categories of permanent bank changes. Table 4 presents hazard rates for causes of temporary suspensions. In each table, row (a) indicates the total number of banks suspending operations. Row (a.1) indicates the total number of banks suspending operations due to problems with assets and liabilities. Imbalances often arose on one side of the balance sheet, but could arise simultaneously on both sides. Rows (a.1.1) through (a.1.5) display the possible combinations: (a.1.1) slow, doubtful, or worthless assets listed as the primary cause of suspension; (a.1.2) assets listed as the primary cause and heavy withdrawals listed as a contributing cause; (a.1.3) both withdrawals and assets listed as primary causes; (a.1.4) heavy withdrawals listed as the primary cause and assets as the contributing cause; and (a.1.5) withdrawals alone as the primary cause of suspension. Row (a.2) indicates the number of banks suspending due to the closure of a correspondent. Row (a.3) indicates the number of banks suspending due to defalcations, mismanagement, excessive loans to officers and directors, excessive investment in building and facilities, and similar circumstances. Row (a.4) indicates the number of banks suspending due to other or multiple causes. The latter consists in part of complex cases which do not fit into the mutually exclusive categories above, often because they spanned two or more classifications. An example is a poorly managed bank which failed to enforce collections on its slow farm loans and which experienced runs after local newspapers revealed that its president embezzled funds from savings accounts. Row (b) indicates the number of consolidations due to financial difficulties. Row 
(c) indicates the number of voluntary liquidations. Row (d) indicates the number of net changes for reasons unrelated to financial difficulties. This series consists almost entirely of the number of mergers minus the number of new openings.

In Table 2, several patterns appear prominent. The share of suspensions due primarily to problems on the asset side of the balance sheet fell through 1931, rose in 1932, and fell again in 1933. The share of suspensions due primarily to withdrawals rose through 1931, fell in 1932, and rose again in 1933. The ratio of assets over withdrawals varied over time. Withdrawals' role in the collapse of the banking system peaked in 1931, while before and after, asset problems caused the majority of suspensions. The share of suspensions due to defalcation and mismanagement fell throughout the depression, perhaps because corrupt and poorly-managed institutions lacked the resources needed to weather the initial states of the storm. The share of suspensions due to the closure of correspondents peaked during 1930.

Figure 6, which plots the number of suspensions each week due to the closure of correspondents (and for sake of comparison also plots total changes due to financial distress), reveals why. The typical week witnessed few, if any, suspensions from this source. The weekly mode and median were zero. The mean was one. The weekly number rose during July of 1929, when the Mediterranean fruit fly epidemic produced a banking panic in Florida, but remained near zero until November 1930, when it spiked sharply upwards.

Figure 7 paints an analogous picture for suspensions whose primary cause was heavy withdrawals. Suspensions due to withdrawals were rare during the initial year of the depression but rose following the collapse of correspondent networks in November 1930. During 1931, when bank suspensions surged repeatedly, withdrawals were a significant cause of suspensions. Thereafter, withdrawals continued to cause suspensions during periods of acute banking distress, but the ratio of withdrawals relative to other causes declined. 
Figure 8 examines the share of suspensions due to correspondents, withdrawals, and assets for the depression as a whole. The left-hand pie chart presents data for banks which suspended operations temporarily. The right-hand pie chart presents data for banks which suspended operations permanently. The shades of gray indicate the percentage of banks suspending for different reasons. The color black denotes banks which suspended solely due to heavy withdrawals (in key, WITHDRAWALS) but which were in fine financial shape before depositors’ demanded repayment of deposits. Most of these banks experienced sudden and severe runs. Three-quarters gray denotes banks forced out of operations by heavy withdrawals and also afflicted by asset troubles that exacerbated their condition, but which were not severe enough to have necessitated suspension in the absence of withdrawals (WITHDRAWAL + assets). One-half gray indicates banks in double trouble. Problems severe enough to necessitate suspension existed on both sides of the balance sheet (WITHDRAWALS \& ASSETS). One-quarter gray indicates banks whose slow, doubtful, and worthless assets forced them to close their doors and where withdrawals exacerbated the situation. Examples include (i) banks forced by continuous, slow withdrawals to sell their profitable assets leaving them with a problematic portfolio, and (ii) banks headed towards failure whose demise was accelerated by depositors’ demands (ASSETS + withdrawals). Lightly-dotted gray indicates banks forced to suspend solely due to problematic assets (ASSETS).

Figure 8 demonstrates that for the contraction as a whole, heavy withdrawals were the primary cause of more than a half of all temporary suspensions. The closure of counterparties caused another sixth of all temporary suspensions. Asset problems were the primary cause of less than a third of the temporary suspensions. For terminal suspensions, the pattern differed. Asset problems were the primary cause of more than half of all bank suspensions and a contributing cause of another one-quarter. More than eight in ten of the banks which went out of business, in other words, were judged to have problematic assets. 
Figure 9 uses the same patterns to portray the cause of suspensions during the fall of 1930 and winter of 1931, a period which witnessed the initial surge of bank suspensions. Before midOctober, the pattern of bank suspensions resembled the pattern of failures throughout the 1920s. Banks failed at a steady rate. The principal cause was problems with asset quality. The pattern changed dramatically in November 1930, when the rate of suspension rose suddenly. The closure of correspondents caused the initial increase. Thereafter, runs (or fear of runs) forced scores of banks to close their doors, and adverse circumstances pushed many weak banks into insolvency.

Comments written on the St. 6386 forms tell the tale. ${ }^{14}$ On November 7, the Bank of Tennessee (Nashville, TN) closed due to "depreciation in the value of securities" and irregularities which left it with "bills payable of $\$ 2,887,100.00$ ” and debts “on real estate of $\$ 260,079.20$ ” on a deposit base of $\$ 10,000,000 .{ }^{15}$ In the following week, heavy withdrawals forced many banks in the city to suspend operations. On November 12, the Holston-Union National Bank (Knoxville, TN) closed due to heavy withdrawals "due to loss of confidence caused by failure of banks in Nashville" and the frozen state of its assets.

On November 17, armageddon arrived. The National Bank of Kentucky (Louisville, KY) suspended operations because of "heavy withdrawals and affiliation with the Caldwell Chain.” The closure forced its affiliate, the Louisville Trust Company, to suspend operations on the same day. During the next week, eleven clients of the national bank suspended operations, as did four clients

14 The archival evidence attributes the suspension of the principal banks controlled by Caldwell conglomerate to either: (a) financial difficulties directly attributed to Caldwell's demise, or (b) runs because of the banks known connection to Caldwell and Company. The archival evidence attributes the suspension of nearly 100 additional banks to: (a) the severing of correspondent links to institutions, such as the Bank of Tennessee, controlled by the Caldwell conglomerate, (b) runs due to known affiliations with the Caldwell organization, or (3) runs due to geographic proximity to Caldwell controlled institutions or geographic proximity to banks undergoing runs.

15 This quotation contains all of the information necessary to locate the cited text in the central subject file of the Board of Governors in the National Archives. The appendix describes how to locate the original sources. 
of the trust company. An additional client closed its doors soon thereafter. The Federal Reserve attributed the suspension of all of those clients to the severance of the correspondent-client linkage.

The American Exchange Trust Company (Little Rock, Arkansas) also suspended operations due to "heavy withdrawals due to rumors caused by failure of Caldwell and Company [in] Nashville.” The American Exchange Trust Company was the lead bank in the A. B. Banks chain and one of the principal correspondent institutions in Arkansas and the surrounding states. Its suspension forced 37 of its clients to suspend operations immediately. Another five suspended operations during the following week. Some of those clients - notably the Arkansas Trust Company (Newport, AR) and the Merchants and Planters Bank and Trust (Pine Bluff, AR) - had clients of their own, which suspended operations in turn.

One client of the American Exchange Trust Company remained in operation for a month. The Citizens Bank and Trust Company (Harrison, AR) endured by calling on the resources of the A. T. Hudsputh Chain, for which it was the principal bank. But on December 17, when those resources ran thin and the loss of funds on deposit in the American Exchange Trust Company appeared irreversible, the Citizens Bank threw in the towel. Within 24 hours, its suspension caused seven of its client banks and the remaining members of the A. T. Hudsputh chain to suspend operations. Similar events occurred in Illinois. On November 8, Quincy-Ricker National Bank and Trust Company (Quincy, IL) suspended operations due to the collapse its largest borrower, the "Smith and Ricker Land and Cattle Company, of Kansas City, Missouri.” Its suspension soon forced four of its client banks to close their doors. During the following week, deposits fell steadily at banks in the vicinity. On November 14, cash reserves of the State, Savings, Loan, and Trust Company (Quincy, IL) ran out. It suspended operations. In the next three days, six of its client banks also closed. Three more did so during the next month. The effects of these suspensions spread across state lines. On November 20, the Hannibal Trust Company (Hannibal, MO) suspended 
operations due to "heavy withdrawals due to closing of a number of banks in their section at Quincy, Illinois.” The closing of the Hannibal Trust Company forced one of its clients, the Farmers Bank (Oakwood, MO), to suspend operations later that afternoon.

Similar chains of collapsing correspondent networks radiated out from Sioux City, Iowa and Clarksdale and Tupelo, Mississippi during December, 1930. On December 6, both the Sioux City National Bank and the First National Bank in Sioux City suspended operations due to "slow, doubtful, or worthless paper.” Two days later, the Leeds Bank of Sioux City, a client of the former, closed its doors. On December 12, the Exchange Bank of Marcus, a client of the latter, ceased operations. On December 17, another client of the latter, The Alvord Bank (Alvord, IA) suspended operations. This was one of the four banks in the Charles Shade chain. The remaining banks of the chain (located in Inkwood, Larchwood, and Rock Rapids, IA) suspended operations at the same time. On December 24, the Peoples Bank and Trust Company (Tupelo, MS) suspended operations due to "excessive bills payable” and "slow, doubtful, and worthless assets.” Its branches at Nettleton and Rienzi closed concurrently. During the next 24 hours, its suspension forced six state banks for which it served as correspondent, located in the towns of Fulton, Guntown, Saltillo, Shannon, Sherman, and Verona, to suspend operations. On December 1930, the Planters National Bank in Clarksdale suspended operations, forcing two of its clients into suspension and inducing banks in neighboring towns to suspended operations for fear of runs.

During the months of November and December, the collapse of correspondent networks triggered numerous bank runs. Comments on cause of suspension forms indicate the cause of these runs was: "general loss of confidence due to failure of banks in Nashville and Knoxville," "loss of confidence and runs," and "runs due to failure of nearby banks." Comments indicate that banks also failed because they were "unable to meet demands" of depositors or consumed their "cash reserves.” Many of these banks possessed from frozen and/or slow assets, which explains why they 
chose to close their doors at a time when depositors drained funds from banks in their vicinity. Comments on banks whose suspensions were attributed to 'assets only' typical indicate that these institutions had preexisting financial problems. Some had frozen assets. Others had devalued assets, which were revealed as a consequence of the crisis following Caldwell's collapse.

The impact of the failure of the Bank of the United States is also evident in the data. It is the second spike in Figure 9. The Bank of the United States possessed one of the largest branch networks in the nation with 57 branches and was the fourth largest bank in New York City and eighth largest in the nation. On the 7th December long queues began forming outside the bank's branches. Over the next four days depositors took out $\$ 20$ million from the bank. On the 11th December, all its branches and the headquarters closed, never to reopen. An even larger institution (hitherto overlooked by economic historians), the Guaranty Building and Loan Association, and its banking subsidiaries, investment houses, and other investment interests headquartered in Hollywood, California failed the preceding day. Their failures appeared on front pages of newspapers around the nation in many places on the same day. On the next day in areas already battered by Caldwell's aftershocks, the number of bank suspensions surged once again.

Following the collapse of Caldwell, the Bank of the United States, and the Guaranty Building and Loan Association, forty percent of the institutions that closed soon reopened. Since they reopened without receiving infusions of capital or other outside assistance and survived the remainder of the depression, they were solvent. Moreover, some banks that closed permanently at this time might have been solvent, if they had not been forced to liquidate when similar institutions in neighboring communities dumped assets on the market, driving down prices, and when a national liquidity crunch forced hundreds of banks (which suspended operations) and thousands of others (beset by withdrawals but able to continue without interruption) to sell bonds and securities, which were their most readily marketable assets, and whose prices fell when their supply suddenly 
expanded. These events are symptoms of a banking system suddenly suffering withdrawals and lacking liquidity.

Lack of liquidity also bedeviled the banking system during the spring of 1931, when suspension surged in Illinois in an event that Friedman and Schwartz (1963) named the Second Banking Crisis. The Federal Reserve attributed only three suspensions to closures of correspondents, one in Florida, one in Nebraska, and one in North Carolina, all far from the locus of suspensions in Illinois, even though Federal Reserve agents indicated that of the 25 banks which suspended in Chicago between June $6^{\text {th }}$ and $10^{\text {th }}$, eleven belonged to the John Bain Group, seven belonged to the Foreman Group, and one belonged to the Ralph E. Ballou and E. L. Wagner Group. For almost all of those suspensions, the Federal Reserve determined heavy withdrawals to have been the primary cause and slow or frozen assets to have been a contributing cause. The same was true of almost all other suspensions in Illinois and adjacent states. Federal Reserve agents stated laconically on most of the forms that the bank closed its doors after depleting its cash reserves. These comments suggest an epidemic of illiquidity plagued banks. Banks' assets were frozen. Depositors wanted cash. Banks closed when they failed to make ends meet.

The pattern of causation changed as time passed. Comments written on the St. 6386 forms illuminate the changes. In September, Britain abandoned the gold standard. Fear that the United States might also devalue its currency triggered the flight of financial assets abroad. In October, to combat the external drain and defend gold, the Federal Reserve raised the discount rate from 1.5\% to $3.5 \%$ and sold substantial quantities of government securities, which reduced the money supply and raised market interest rates. These actions weakened the financial positions of banks throughout the nation. Depositors grew increasingly apprehensive about the health of depository institutions. Bank suspensions surged once again, and suspension rates remained elevated through the winter of 1932. During this period, banks failed for a wide array of reasons. Heavy withdrawals from healthy 
banks caused 20\% of the suspensions. Heavy withdrawals from banks beset by portfolio problems caused $40 \%$ of the suspensions. Depreciated assets caused $24 \%$ of the suspensions. For many of these banks, written comments indicated that droughts, declines in agricultural prices, depressions of local industries, and depreciations of bonds' values and securities' prices had reduced the value of the bank’s portfolio so far as to necessitate suspension.

During the spring of 1932, the Federal Reserve initiated an open-market purchase program in an attempt to reinvigorate banks and reinflate the economy. The attempt lasted only a few months. During that period, suspensions fell to their lowest level since the fall of 1930. Withdrawals also eased. Liquidity appears to have been available. The majority of the banks that suspended operations did so principally due to problems on the asset side of their balance sheet.

This pattern held true even during the month of June, when a banking crisis plagued the city of Chicago and surrounding environs. During that panic, some solvent banks experienced runs, but the solvent institutions which suspended operations soon reopened. Devalued assets were the primary cause of most terminal suspensions, while withdrawals were noted as only a contributing condition, if they were mentioned at all. Written comments on the suspension forms indicate that banks were struggling due to declines in the values of securities, bonds, and real estate and losses due to uncollectible and defaulted loans. In other words, during this event, most banks which experienced runs were either insolvent or teetering on the edge of bankruptcy. Illiquidity and runs did not destroy solvent institutions. Real economic forces caused their demise.

In November 1932, Franklin Roosevelt won the presidential election. Expectations that the new Democratic administration would abandon the gold standard induced foreigners to ship funds abroad and Americans to convert deposits to precious metals. The Federal Reserve lacked the resources to counter these external and internal drains. Some districts (e.g. Atlanta) extended credit freely to ailing institutions. Other districts (e.g. New York) had to choose between aiding banks and 
preserving their dwindling stocks of gold. Policies lacked consistency across districts, and some districts (e.g. Chicago) refused to cooperate with others despite their statutory obligation to do so. Bank suspensions rose steadily during this period. Banks failed for many, and usually multiple, reasons. Three-out-of-four suspensions suffered both asset problems and heavy withdrawals. Only a handful of banks that suspended operations ever reopened, and in every case, their resurrection required outside financial assistance.

Figure 10 combines information from the previous figures to address a perennial question concerning the depression: did (a) contagion and illiquidity or (b) fundamentals and falling asset values cause banks to fail? The answer is that both were important sources of bank distress. Failures due to the former were concentrated during crises, during which contagion and illiquidity caused between one-third and one-half of all suspensions. Failures caused by fundamentals predominated before November 1930, during the lulls between panics, and after Britain abandoned the gold standard and the Federal Reserve embarked on a contractionary policy to counter gold outflows. Outside of panic periods, contagion and illiquidity caused a small fraction of all suspensions, while fundamentals caused the preponderance

Figure 10 justifies this answer by providing two estimates of banks failing due to contagion and illiquidity. The lower bound is 1,376 or approximately one-fifth of all banks which suspended operations between January 1929 and March 1933. The lower bound estimate consists of all banks which (i) temporarily suspended operations and reopened within three months without outside financial assistance, (ii) permanently suspended operations after experiencing heavy withdrawals and for no other reason (i.e. the examiners judged their assets to be in satisfactory condition), (iii) permanently suspended operations after being forced to close by the closure of a counterparty. The upper bound is 2,739 or approximately one-half of all suspended banks. The upper bound consists of banks in categories (i), (ii), and (iii) plus banks which suspended operations permanently (iv) 
after experiencing heavy withdrawals and possessing assets which examiners judged to be frozen or slow, (v) because they had exhausted their borrowing capacity, were unable to borrow, or failed to obtain loans from their correspondent, or (vi) because they had exhausted their cash reserves. Written comments on the St. 6386 forms identify banks in categories (v) and (vi).

\section{5: Discussion}

The evidence presented in the previous section corroborates the arguments of many scholars. As Temin (1976) and White (1984) maintain, large numbers of banks liquidated during the 1920s. Thos banks often operated in rural areas and incurred large losses on loans. This trend continued throughout the depression and intensified as the downturn deepened.

As Wicker (1980) argues, the collapse of the Caldwell conglomerate triggered the initial banking panic in the fall of 1930. Correspondent networks propagated the panic during the initial weeks, when almost all of the banks which suspended operations were financially or geographically connected to the Caldwell conglomerate. Bank runs radiated outward from these focal events. Heavy withdrawals became the principal form of bank distress and forced hundreds of banks to suspend operations. Yet, as Friedman and Schwartz (1963) argue, the failure of the Bank of the United States accentuated depositors' fears and reinvigorated the panic. All three scholars, Friedman, Schwartz, and Wicker, argue that the crisis was a departure from previous trends, a unique event that may have altered the course of the contraction. The archival evidence supports a synthesis of their views, while revealing additional aspects of the event. Several smaller correspondent chains, with no connection to Caldwell, imploded at that time. The failure of the Guaranty Building and Loan Association added fuel to the fire. Nearly half of the institutions that suspended operations as a consequence of these events rapidly reopened for business. 
As Friedman and Schwartz (1963) contend, illiquidity played a role in the surge in bank suspensions in June of 1931. In that month, runs occurred on banks in Illinois. Examiners reported that heavy withdrawals were the primary cause of almost all of these suspensions. Frozen assets and limited cash reserves contributed to many closures, but none of the banks possessed portfolios which had deteriorated near the point of insolvency.

As Calomiris and Mason (1997) maintain, the Chicago banking panic of June 1932 was due to depositors' confusion about bank asset quality. Examiners reported that for most banks which entered receivership, the primary cause of suspensions was doubtful and worthless assets. The banking panic did not produce significant numbers of failures among solvent banks.

For the remainder of the contraction, the causes of bank suspensions fit the descriptions of events offered by Temin (1976) and Calomiris and Mason (2003). Declining asset values were the principal cause of bank suspensions. Most banks which closed their doors did so permanently. All were insolvent. The few which reopened did so only after receiving outside financial assistance.

The archival evidence shows that scholars accurately interpreted their own data, but because the nature of the financial crisis varied across time, place, and institutions, no single sample could capture the complexity and dynamism of events. During the last two decades, samples brought to bear on the debate typically consisted of data on national and member banks. Liquidation was the observed outcome. So, recent research emphasized insolvency. The data introduced in this essay concurs with those conclusions but adds information on illiquidity. The new observations show that illiquidity bedeviled banks beginning in the fall of 1930. Insolvency returned as the principal form of distress in the years which followed.

Why did the nature of the banking crisis change over time? The archival evidence illuminates the initial impetus. A series of events revealed the fragility of the banking system which had evolved since the foundation of the Federal Reserve. During the 1920s, financial markets 
changed rapidly. Entrepreneurs invented new financial instruments and forms of consumer credit. Individual investment in the equity markets increased rapidly and haphazardly. Markets became more tightly integrated across space and time. Financial conglomerates grew to take advantage of new opportunities. These innovative organizations included banking chains and groups. Some organizations spanned commercial and investment banking, insurance, real estate, equity trading, and brokerage services. These conglomerates enabled businesses and individuals to access the rapidly modernizing financial system.

In November and December 1930, these new and supposedly superior institutions showed signs of weakness. Correspondent networks (such as Caldwell's) collapsed. Banking chains (such as A.B. Banks) failed. Banking groups (such as BancoKentucky) also failed. Three prominent conglomerates - Caldwell in middle America, the Bank of the United States in New York, and the Guaranty Building and Loan Association in California - failed. Their failures resulted in three of the largest bankruptcies in United States to that date. Scandals swirled around each bankruptcy. Defalcation undermined each institution. False financial reports deceived investors and depositors, who lost large sums as a result. For months, newspapers throughout the nation reported the scandals at length and in depth on their front pages. The news altered depositors' beliefs about the safety, stability, and efficacy of the system. The public reacted by withdrawing funds, increasing holdings of currency, and switching savings to safer, older, and more transparent institutions.

This argument explains the liquidity crunch that began in the fall of 1930 and lasted through the spring of 1931. What explains the continued contraction of the banking system? Answers to this question can be divided into two classes. The first follows the logic of Friedman and Schwartz (1963). The liquidity crisis grew like a snowball rolling down a hill. The initial credit crunch forced some banks out of business. Fear of further failures induced depositors to withdraw additional funds, which forced banks to sell more assets, which drove asset prices even lower, which forced 
more banks to fail, which confirmed depositors’ fears in a continuing cycle of self-fulfilling pessimism. The snowball stopped only when Roosevelt declared a national banking holiday in the winter of 1933 and restored confidence in the safety and soundness of the financial system.

The second follows the logic of Temin (1989). Shocks - droughts, tariff wars, contractionary policies, beggar-thy-neighbor devaluations, declines in autonomous consumption and investment - battered the economy in the early 1930s. England's departure from the gold standard was a particularly severe stimulus. These real shocks reduced asset values and pushed marginal banks into insolvency. The banking crisis came to an end only after economic recovery began in 1933.

The information presented in this essay cannot distinguish between these theories. Both are consistent with the data. Both probably explain a portion of events. Their relative explanatory power remains one of the key unanswered questions concerning the depression.

The patterns presented in this essay answer some but far from all questions concerning the causes and consequences of bank failures during the Great Depression. Viewing the data from different perspectives may resolve other riddles. One possibility is comparing the causes of national versus state bank suspensions. A second possibility is comparing the causes of member versus nonmember bank suspensions. Such exercises may help to reconcile the conclusions of Calomiris and Mason (2003), Carlson (2004), and White (1984), who study microdata from member, state, and national banks respectively, with those of Mitchener (2004) and Wicker (1996), who study data on state bank suspensions aggregated at the county, state, and Federal Reserve District levels. Additional insights may be gleaned by comparing urban and rural banks or by examining suspension patterns geographically or weighted by bank size (e.g. assets, liabilities, or capital) or weighted by the length of temporary suspensions (e.g. number of days). 
The archival evidence introduced in this essay may also illuminate the transmission mechanisms of monetary policy and the linkages between the financial crisis and real economy. Terminal suspensions disrupted financial intermediation and increased the costs of credit intermediation to a greater extent than temporary suspensions. Temporary suspensions were symptoms of liquidity crises and banking panics propelled by sudden swings in depositors' moods. By distinguishing these events, the archival data provides mechanisms for illuminating the monetary and non-monetary effects of financial panics and the ways in which Federal Reserve action (or inaction) contributed to the collapse of the economy.

These analyses are topics for future essays. My preliminary explorations along each dimension indicate that none contradict the conclusions justified by the chronological patterns presented in this essay. Illiquidity bedeviled banks throughout the depression. Heavy withdrawals played a primary or contributing role in nearly half of all suspensions. Asset problems also bedeviled banks throughout the Great Depression. Slow, doubtful, or worthless assets played a primary or contributing role in over half of all suspensions. The initial banking panic in the fall of 1930 - with its cluster of temporary bank suspensions, bank runs, and collapsing correspondent networks - appears to have been a credit crunch inspired by the collapse of financial conglomerates and propagated by the public’s flight from deposits to currency. During later surges in banking crises, the suspension of depository institutions appears to have been driven less by sudden swings in depositors' fears for the safety of banks and more by declines in the values of banks' portfolios.

These conclusions raise new questions concerning the collapse of the banking system during the 1930s. Why did correspondent networks collapse in November and December 1930 but endure even greater shocks during the following three years? Why did some banks which suspended operations reopen for business, while others whose owners and managers also strove to reorganize and reopen, fail to reopen their doors? Why were banks able to avoid suspension by merging with 
healthy institutions at the last minutes in some states but not in others? Did the policies pursued by state banking departments and Federal Reserve Banks influence the categories and causes of bank changes under duress? Future essays employ the new archival evidence to answer such questions and to advance our efforts to understand the causes and consequences of financial distress during the Great Depression. 
Figure 1

Comparing Archival and Published Data

Total Suspensions, All Banks, by Month, September 1929 to March 1933

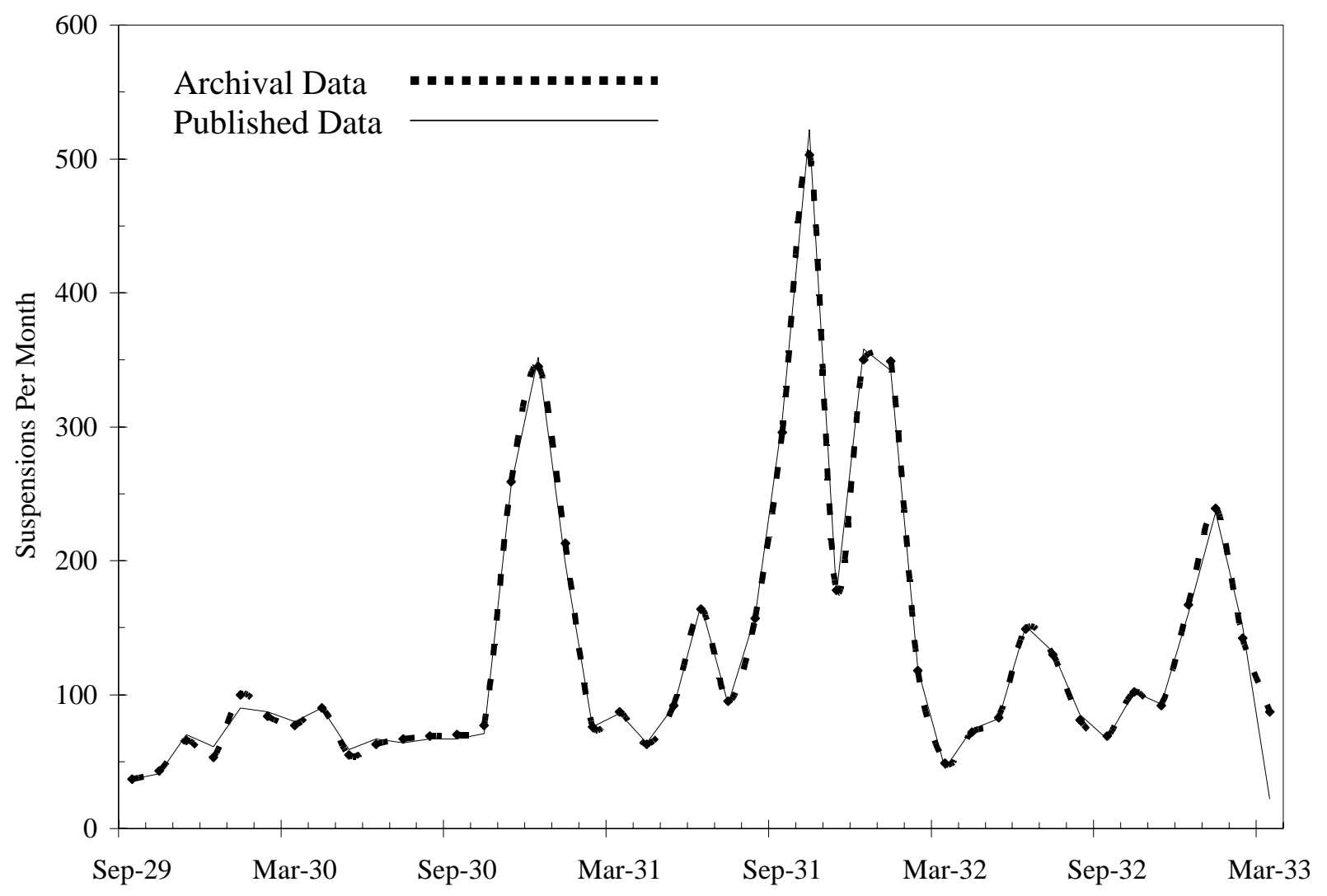

Sources: Archival data from National Archives and Record Administration, Record Group 82, as described in appendix. Published data from Federal Reserve Bulletin, September 1937, Table 12, p. 907 
Figure 2

Comparing FRB’37 and Archival Data, January 1929 through December 1933

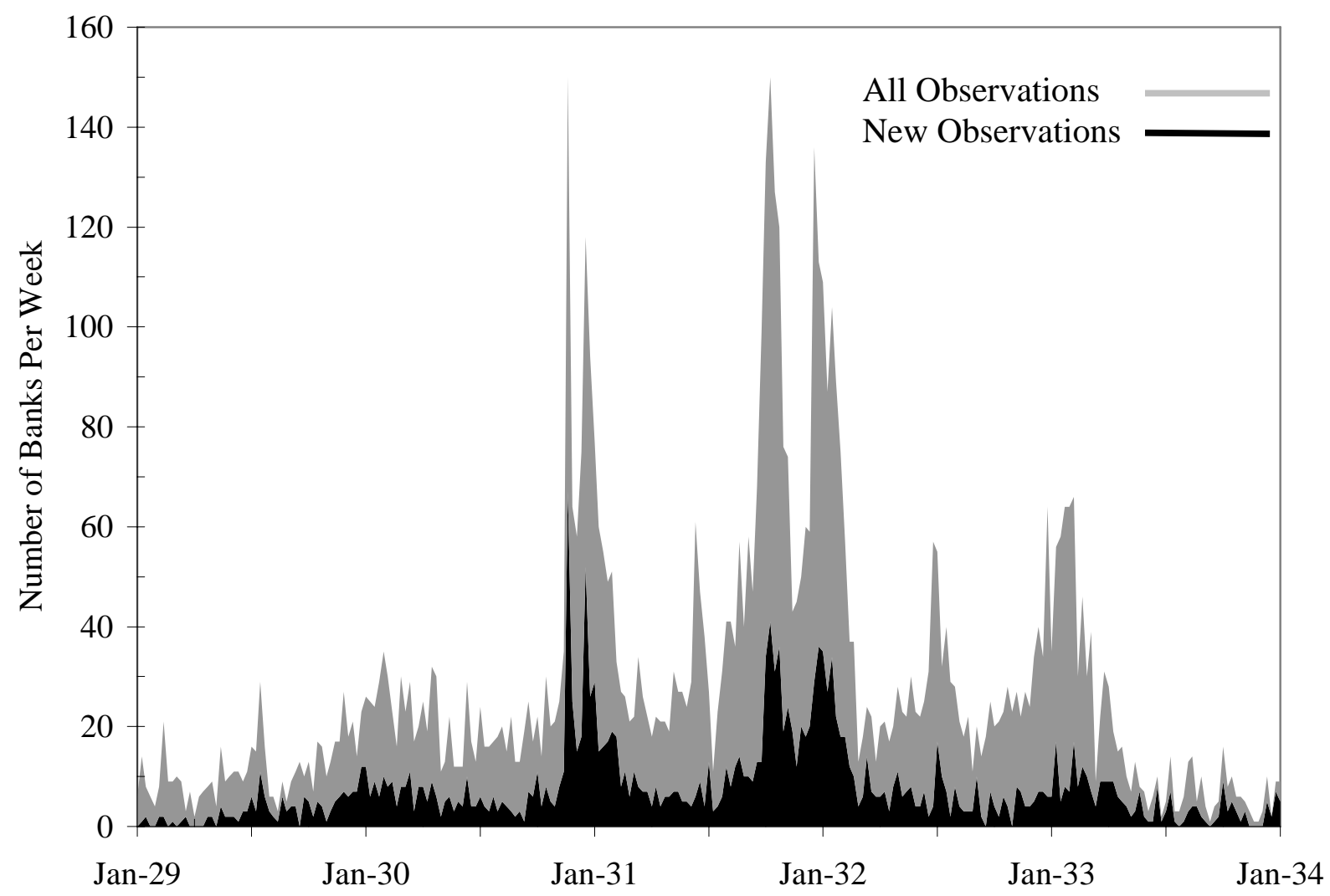

Source: National Archives and Records Administration. 
Figure 3

Terminal and Temporary Bank Suspensions, January 1929 through March 1933

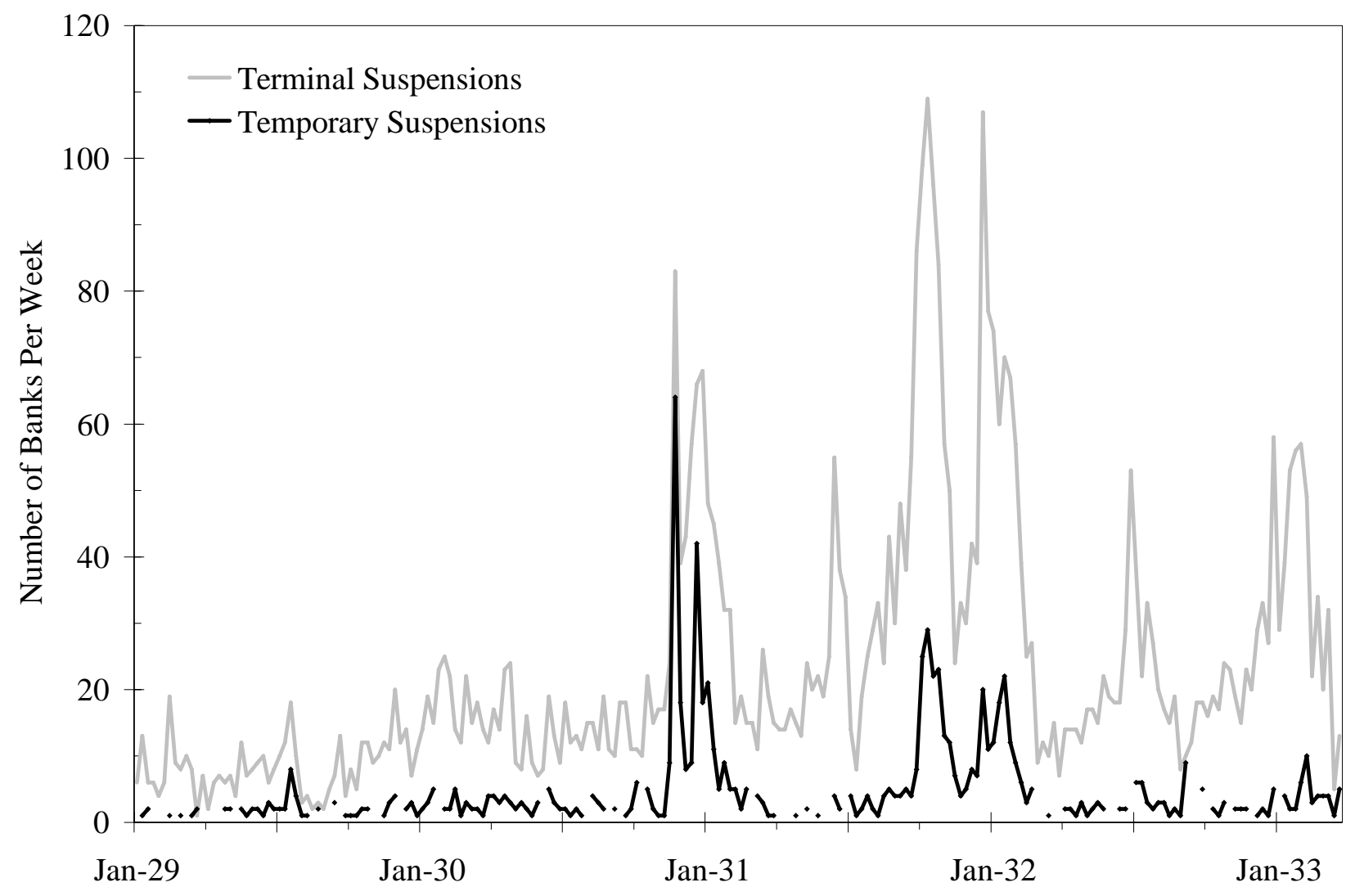

Source: National Archives and Record Administration. 
Figure 4

Consolidations Due to Financial Difficulties and Voluntary Liquidations January 1929 through March 1933

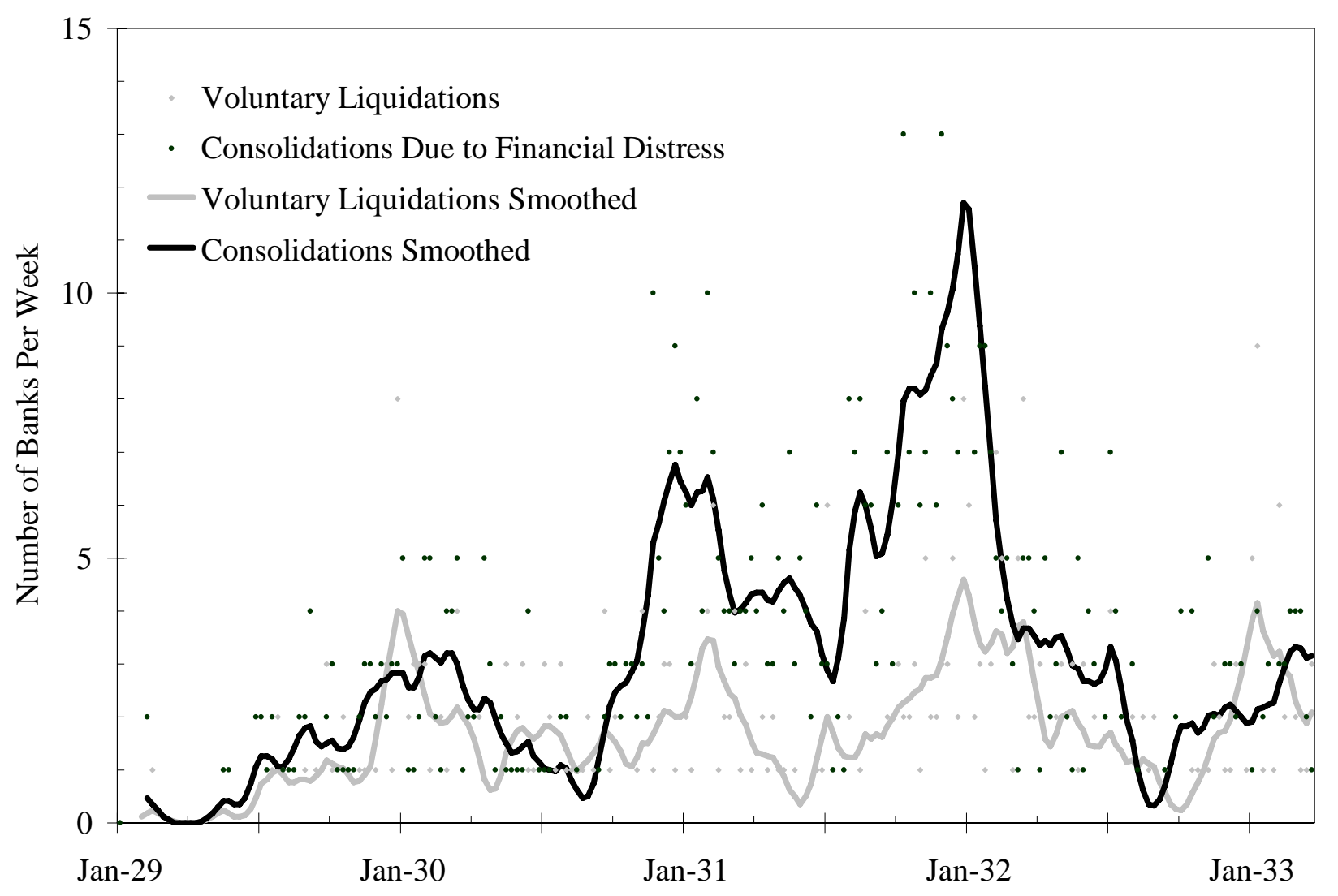

Notes: Consolidations and liquidations are smoothed using Epanechnikov kernel filters with bandwidth equal to four weeks.

Source: National Archives and Record Administration. 
Figure 5

Solvency and Insolvency among Banks Departing the Banking Business Each Year January 1929 through March 1933

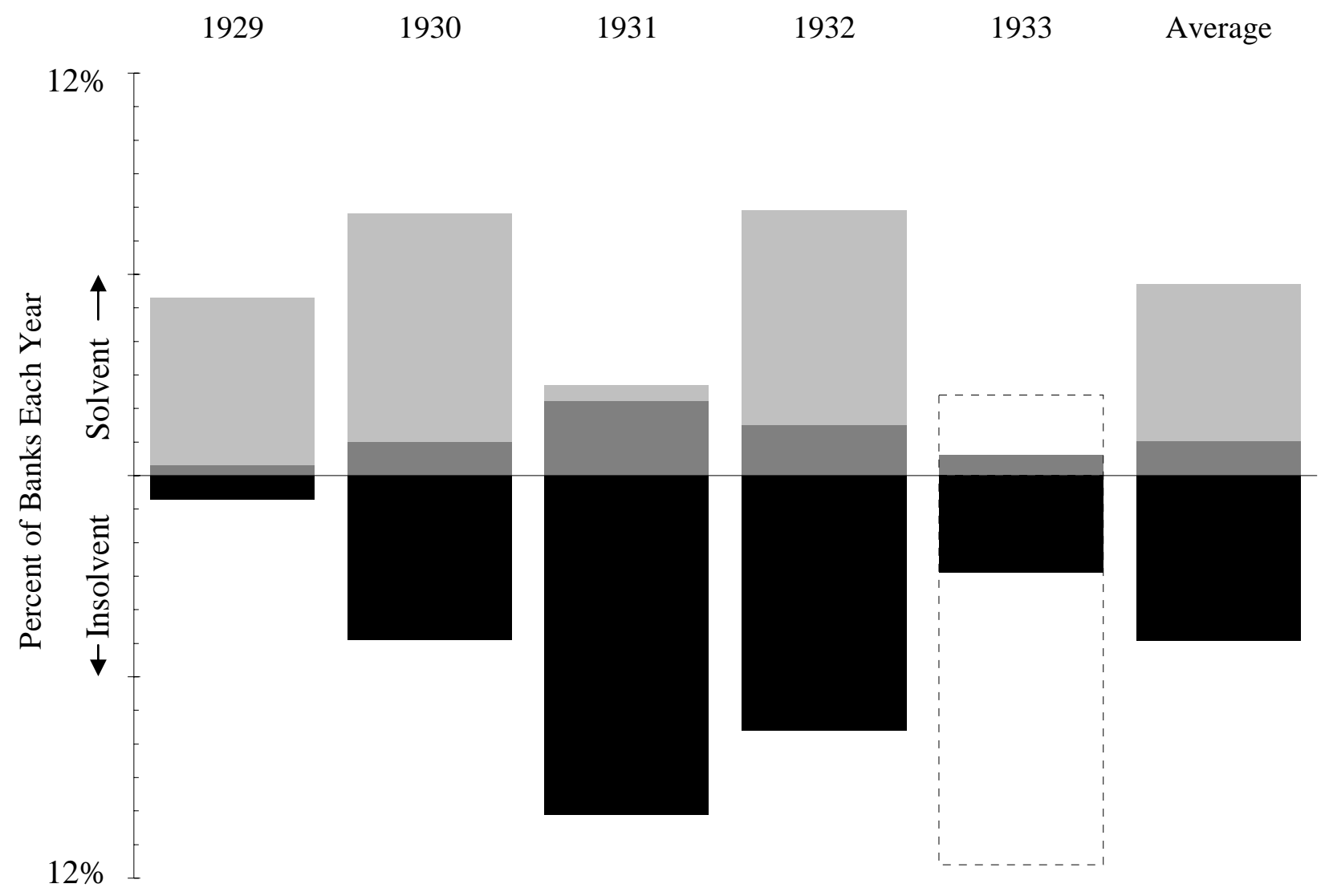

Notes: Figures for 1933 include only changes occurring in January through March except those which occurred to institutions closed by government proclamation of banking moratoria or holidays.

Source: National Archives and Records Administration and FRB'37. 
Figure 6

Suspensions Due to Closures of Correspondents, January 1929 through March 1933

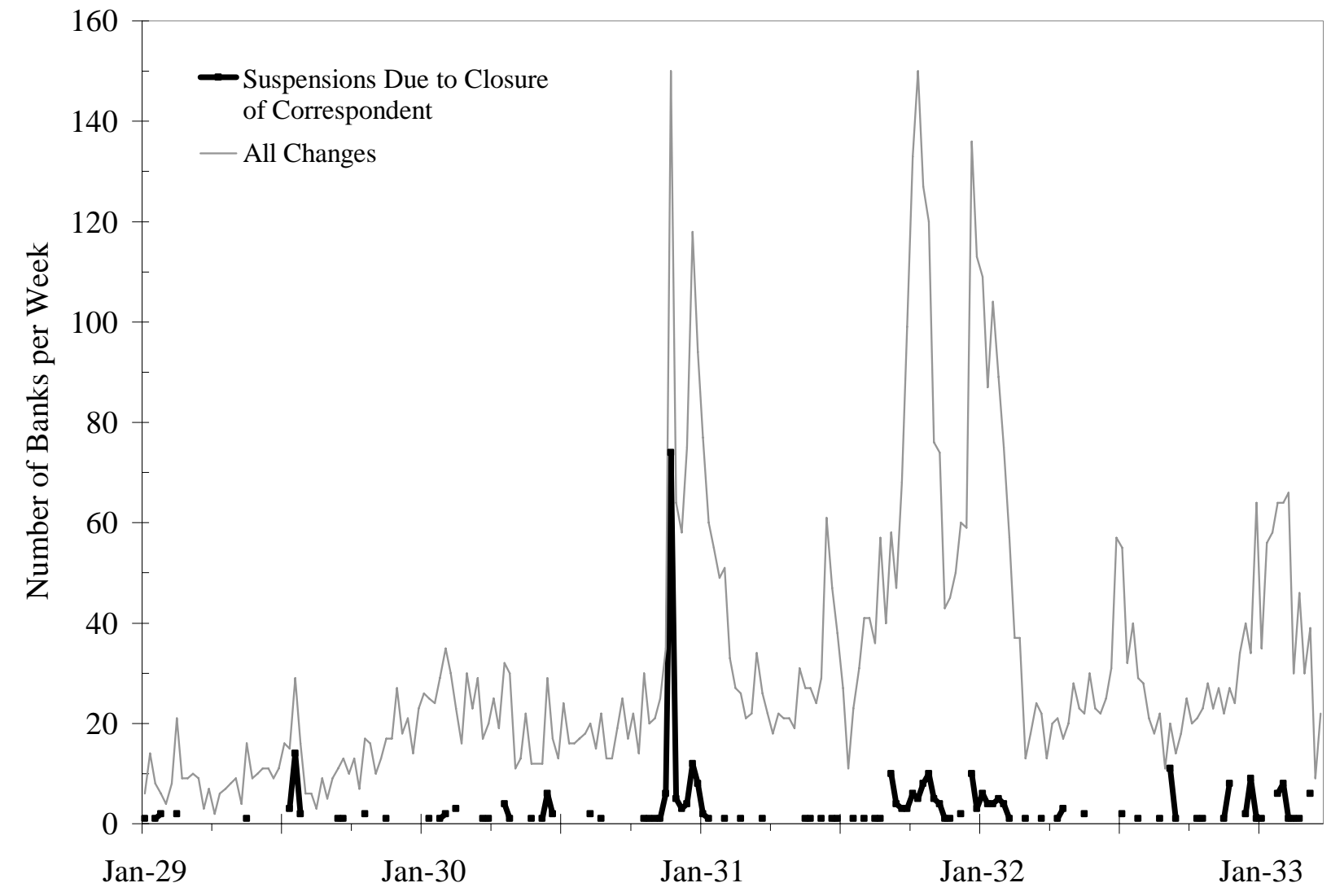

Source: National Archives and Record Administration. 
Figure 7

Suspensions Due to Heavy Withdrawals (as primary cause), January 1929 through March 1933

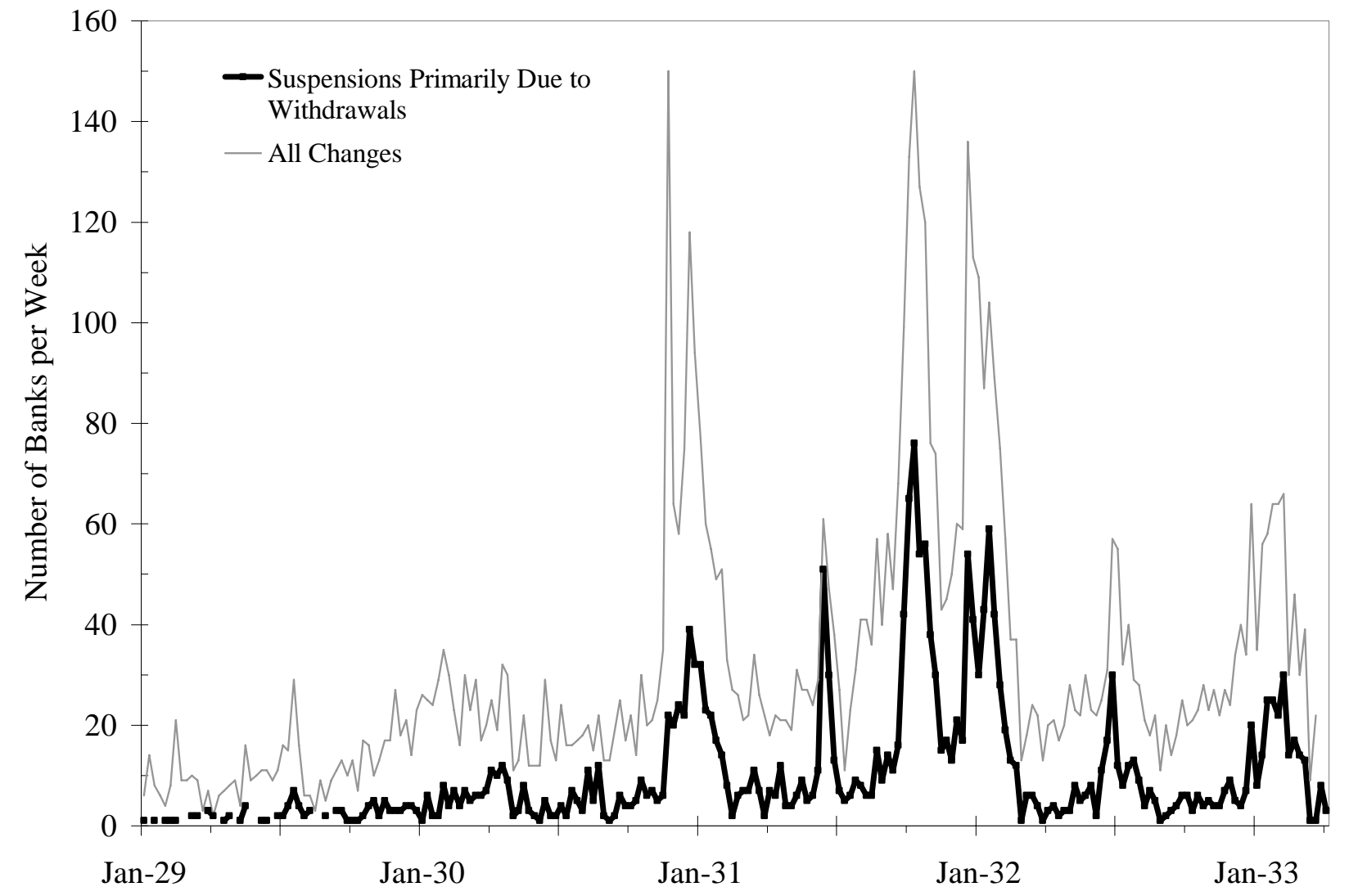

Source: National Archives and Records Administration. 
Figure 8

Causes of Suspensions, Percent of Totals, January 1929 through March 1933

\section{$\square$ Assets}

$\square$ Assets + withdrawals Withdrawals \& assets

$\square$ Withdrawals + assets

Withdrawals

$\boldsymbol{Z}$ Correspondents

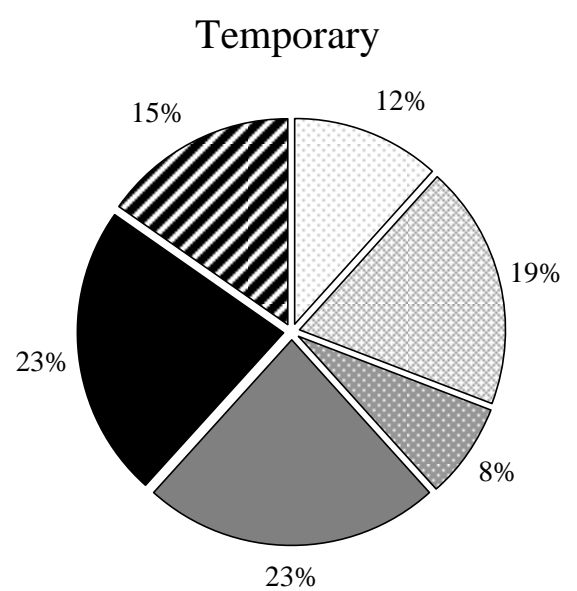

Terminal

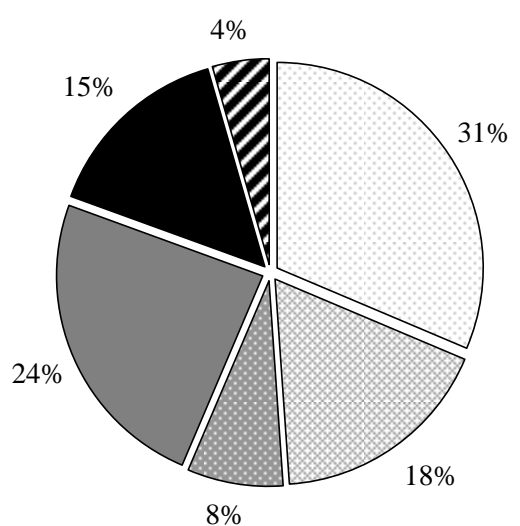

Note: The pie charts above display the proportion of suspensions occurring between January 1929 and March 1933 attributed to the 6 causes listed above. Suspensions attributed to defalcation, mismanagement, multiple, and other causes were excluded from the calculations. The proportions of suspensions attributed to those causes were roughly equal.

Source: National Archives and Records Administration. 
Figure 9

Causes of Suspension during the First Banking Crisis, September 1930 through March 1931

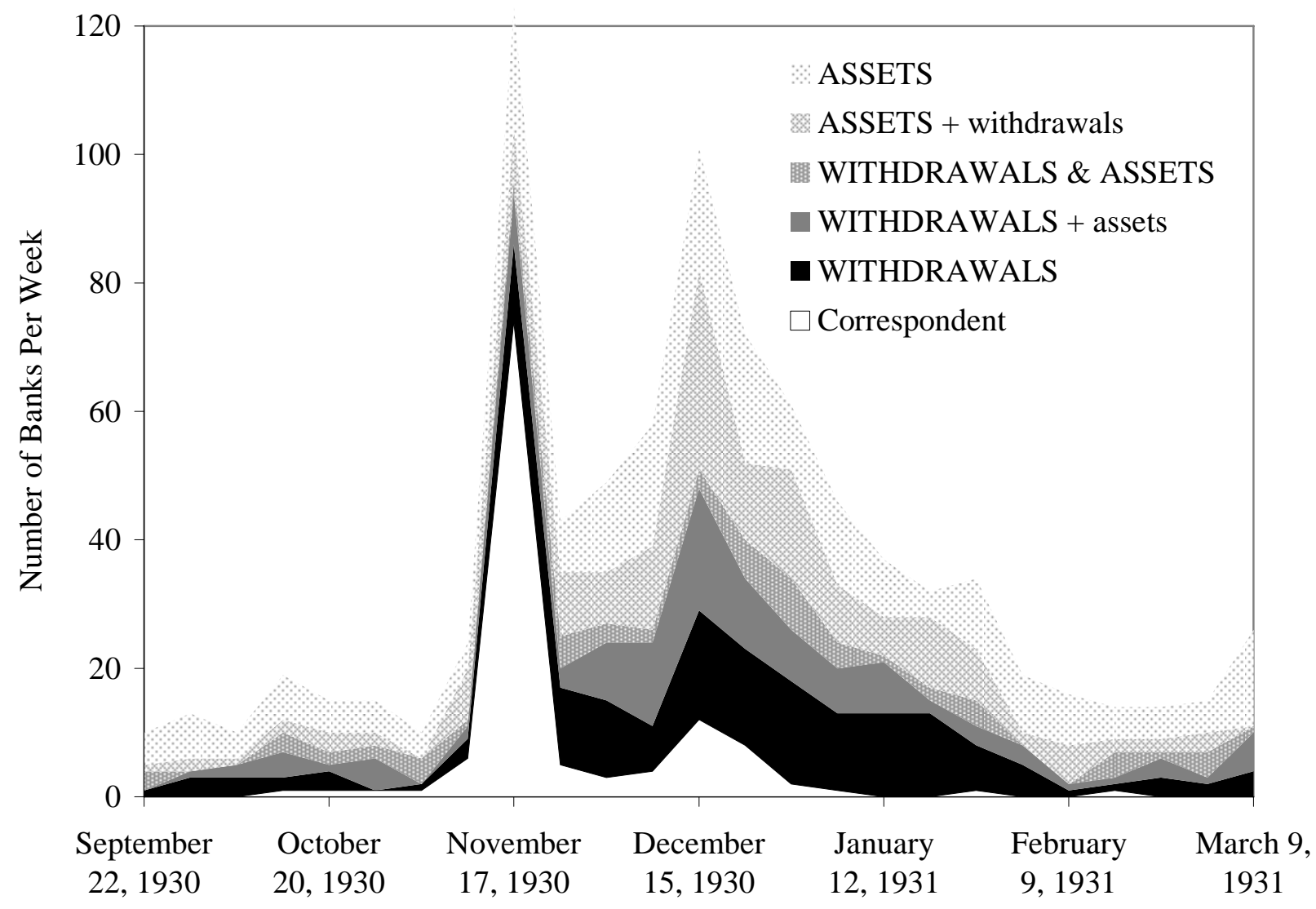

Source: National Archives and Record Administration. 
Figure 10

Suspensions Due to Contagion and Illiquidity, January 1929 through March 1933

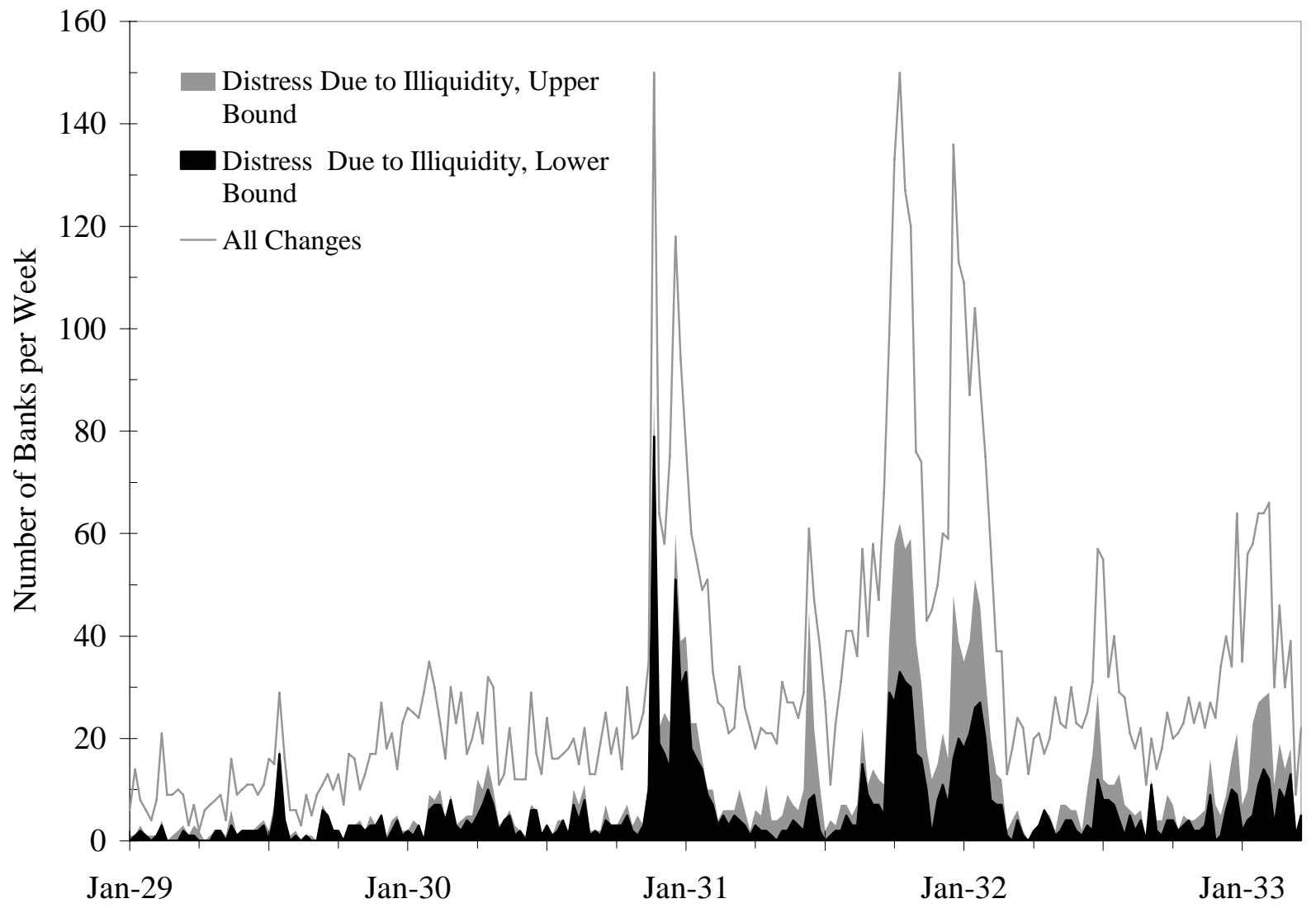

Source: National Archives and Records Administration. 
Table 1

Bank Changes Due to Financial Difficulties by Category and Year January 1929 through March 1933

\begin{tabular}{lrrrrrr}
\hline Categories & 1929 & 1930 & 1931 & 1932 & 1933 & Total \\
\hline Suspensions, Terminal & 433 & 1078 & 1958 & 1300 & 420 & 5189 \\
Suspensions, Temporary & 70 & 278 & 316 & 161 & 48 & 874 \\
Consolidations Due to Financial Difficulties & 54 & 136 & 309 & 151 & 38 & 688 \\
Voluntary Liquidations & 39 & 86 & 110 & 99 & 37 & 371 \\
& & & & & & \\
\hline Total & 596 & 1578 & 2693 & 1712 & 543 & 7122 \\
\hline
\end{tabular}

Note: Statistics for 1933 include only the months January through March. Figures do not include c banks closed due to government proclamations, moratoria, or banking holidays.

Source: National Archives and Records Administration.

Table 2

Causes of Suspensions

January 1929 through March 1933

\begin{tabular}{lrrrrrr}
\hline Causes of Suspensions & 1929 & 1930 & 1931 & 1932 & 1933 & Total \\
\hline & 242 & 848 & 1720 & 1125 & 337 & 4272 \\
(a.1) Assets and Liabilities & 102 & 316 & 457 & 354 & 91 & 1320 \\
(a.1.1) Assets & 44 & 142 & 294 & 250 & 61 & 791 \\
(a.1.2) Assets (p) and withdrawals (c) & 16 & 71 & 163 & 74 & 22 & 346 \\
(a.1.3) Assets (p) and withdrawals (p) & 38 & 145 & 487 & 294 & 116 & 1080 \\
(a.1.4) Withdrawals (p) and assets (c) & 42 & 174 & 319 & 153 & 47 & 735 \\
(a.1.5) Withdrawals & 28 & 140 & 97 & 68 & 24 & 357 \\
(a.2) Closure of correspondent & 143 & 153 & 159 & 76 & 16 & 547 \\
(a.3) Defalcation and mismanagement & 90 & 215 & 298 & 193 & 91 & 887 \\
(a.4) Other and multiple causes & & & & & & \\
\hline Total & 503 & 1356 & 2274 & 1462 & 468 & 6063 \\
\hline
\end{tabular}

Note: Statistics for 1933 include only the months January through March. Figures do not include c banks closed due to government proclamations, moratoria, or banking holidays. Rows (a.1.1) through (a.1.5) indicate subtotals of line (a.1).

Source: National Archives and Records Administration. 
Table 3

Categories and Causes of Permanent Bank Changes, Annual Hazard Rates, January 1929 through March 1933

\begin{tabular}{|c|c|c|c|c|c|c|c|c|c|c|c|c|}
\hline \multirow[b]{3}{*}{ Banks at beginning of yeal } & \multicolumn{2}{|r|}{1929} & \multicolumn{2}{|r|}{1930} & \multicolumn{2}{|r|}{1931} & \multicolumn{2}{|r|}{1932} & \multicolumn{2}{|c|}{1933} & \multicolumn{2}{|r|}{ Total } \\
\hline & $\%$ & $\#$ & $\%$ & $\#$ & $\%$ & $\#$ & $\%$ & $\#$ & $\%$ & $\#$ & $\%$ & \# \\
\hline & \multicolumn{2}{|c|}{24,198} & \multicolumn{2}{|r|}{22,172} & \multicolumn{2}{|r|}{19,375} & \multicolumn{2}{|r|}{17,082} & \multicolumn{2}{|c|}{14,440} & \multicolumn{2}{|r|}{24,198} \\
\hline (a) Terminal suspensions due to & 1.79 & 433 & 4.86 & 1,078 & 10.11 & 1,958 & 7.61 & 1,300 & 2.91 & 420 & 21.44 & 5,189 \\
\hline (a.1) Assets and liabilities & 0.88 & 212 & 3.18 & 704 & 7.70 & 1,491 & 5.91 & 1,010 & 2.15 & 310 & 15.40 & 3,727 \\
\hline (a.1.1) Assets & 0.39 & 95 & 1.32 & 293 & 2.22 & 430 & 1.98 & 338 & 0.60 & 86 & 5.13 & 1,242 \\
\hline (a.1.2) Assets (p) and withdrawals (c) & 0.17 & 42 & 0.51 & 114 & 1.29 & 250 & 1.25 & 214 & 0.40 & 58 & 2.80 & 678 \\
\hline (a.1.3) Withdrawals (p) and assets (p) & 0.05 & 11 & 0.27 & 59 & 0.70 & 135 & 0.42 & 71 & 0.13 & 19 & 1.22 & 295 \\
\hline (a.1.4) Withdrawals (p) and assets (c) & 0.13 & 32 & 0.51 & 113 & 2.24 & 434 & 1.46 & 250 & 0.73 & 106 & 3.86 & 935 \\
\hline (a.1.5) Withdrawals & 0.13 & 32 & 0.56 & 125 & 1.25 & 242 & 0.80 & 137 & 0.28 & 41 & 2.38 & 577 \\
\hline (a.2) Closure of corresponden & 0.09 & 22 & 0.35 & 78 & 0.40 & 77 & 0.29 & 50 & 0.14 & 20 & 1.02 & 247 \\
\hline (a.3) Defalcation and mismanagemen & 0.51 & 123 & 0.59 & 130 & 0.73 & 142 & 0.43 & 74 & 0.11 & 16 & 2.00 & 485 \\
\hline (a.4) Other causes & 0.31 & 76 & 0.75 & 166 & 1.28 & 248 & 0.97 & 166 & 0.51 & 74 & 3.02 & 730 \\
\hline (b) Consolidations due to difficultie & 0.22 & 54 & 0.61 & 136 & 1.59 & 309 & 0.88 & 151 & 0.26 & 38 & 2.84 & 688 \\
\hline (c) Voluntary liquidations & 0.16 & 39 & 0.39 & 86 & 0.57 & 110 & 0.58 & 99 & 0.26 & 37 & 1.53 & 371 \\
\hline (d) Net changes for other reasons & 6.20 & 1,500 & 6.75 & 1,497 & -0.43 & -84 & 6.39 & 1,092 & & & 16.55 & 4,005 \\
\hline Banks at end of year & & 22,172 & & 19,375 & & 17,082 & & 14,440 & & ,945 & & 13,945 \\
\hline
\end{tabular}

Notes: Statistics for 1933 include only the months January through March. The initial entry is the number of banks operating at the beginning of January 1929. For each year, the percentage column indicates the fraction of the banks operating in that year which experienced each event. For the total column, the percentage indicates the fraction of banks which experienced each event at some point in time from January 1929 to March 1933. (p) indicates a primary cause. (c) indicates a contributing cause.

Sources: Data on banks in operation from Wicker 1996, Table 1.1, page 2 and Federal Reserve Bulletin, September 1937, Table 12, p. 907. Suspension data from Record Group 82, National Archives and Records Administration. 
Table 4

Categories and Causes of Temporary Bank Changes, Annual Hazard Rates, January 1929 through March 1933

Banks at beginning of year

(a) Temporary suspensions due to

(a.1) Assets and liabilities
(a.1.1) Assets
(a.1.2) Assets (p) and withdrawals (c)
(a.1.3) Withdrawals (p) and assets (p)
(a.1.4) Withdrawals (p) and assets (c)
(a.1.5) Withdrawals
(a.2) Closure of correspondent
(a.3) Defalcation and mismanagement
(a.4) Other causes

\begin{tabular}{|c|c|c|c|c|c|c|c|c|c|c|c|}
\hline \multicolumn{2}{|c|}{1929} & \multicolumn{2}{|c|}{1930} & \multicolumn{2}{|c|}{1931} & \multicolumn{2}{|c|}{1932} & \multicolumn{2}{|c|}{1933} & \multicolumn{2}{|c|}{ Tota } \\
\hline$\%$ & \# & $\%$ & \# & $\%$ & \# & $\%$ & $\#$ & $\%$ & $\#$ & $\%$ & \# \\
\hline \multicolumn{2}{|c|}{24,198} & \multicolumn{2}{|c|}{22,172} & \multicolumn{2}{|c|}{19,375} & \multicolumn{2}{|c|}{17,082} & \multicolumn{2}{|c|}{14,440} & \multicolumn{2}{|c|}{23,594} \\
\hline 0.29 & 70 & 1.25 & 278 & 1.63 & 316 & 0.94 & 161 & 0.33 & 48 & 3.70 & 873 \\
\hline 0.12 & 30 & 0.65 & 144 & 1.18 & 229 & 0.67 & 114 & 0.19 & 27 & 2.31 & 544 \\
\hline 0.03 & 7 & 0.10 & 23 & 0.14 & 27 & 0.09 & 16 & 0.03 & 5 & 0.33 & 78 \\
\hline 0.01 & 2 & 0.13 & 28 & 0.23 & 44 & 0.20 & 35 & 0.02 & 3 & 0.47 & 112 \\
\hline 0.02 & 5 & 0.05 & 12 & 0.14 & 28 & 0.02 & 3 & 0.02 & 3 & 0.22 & 51 \\
\hline 0.02 & 6 & 0.14 & 32 & 0.27 & 53 & 0.26 & 44 & 0.07 & 10 & 0.61 & 145 \\
\hline 0.04 & 10 & 0.22 & 49 & 0.40 & 77 & 0.09 & 16 & 0.04 & 6 & 0.67 & 158 \\
\hline 0.02 & 6 & 0.30 & 67 & 0.10 & 20 & 0.11 & 18 & 0.03 & 4 & 0.49 & 115 \\
\hline 0.09 & 21 & 0.11 & 24 & 0.09 & 17 & 0.01 & 2 & & & 0.27 & 64 \\
\hline 0.05 & 13 & 0.19 & 43 & 0.26 & 50 & 0.16 & 27 & 0.12 & 17 & 0.64 & 150 \\
\hline
\end{tabular}

Notes: Statistics for 1933 include only the months January through March. The initial entry is the number of banks operating at the beginning of January 1929. For each year, the percentage column indicates the fraction of the banks operating in that year which experienced each event. For the total column, the percentage indicates the fraction of banks which experienced each event at some point in time from January 1929 to March 1933. (p) indicates primary cause. (c) indicates contributing cause.

Sources: Data on banks in operation from Wicker 1996, Table 1.1, page 2 and Federal Reserve Bulletin, September 1937, Table 12, p. 907. Suspension data from National Archives and Records Administration, Record Group 82. See appendix for details. 


\section{Appendix}

This appendix contains three parts. The first describes the location, organization, and procedures for citation of the archival evidence. The second discusses when, where, why, and how the Board of Governors collected this information and issues important for interpreting empirical work based upon this new and unique source. The discussion emphasizes the methods that Federal Reserve agents employed to ascertain the causes of bank suspensions and the lexicon that the Board of Governors devised during the 1920s to facilitate their analysis. The discussion cites the memos and training materials distributed to Federal Reserve employees undertaking this task and outlines the algorithms that they employed when analyzing the evidence. The third part of the appendix delves into details of the data collection process and the procedures that the Federal Reserve used to validate and cross-check the evidence. The purpose of the extended discussion is to reassure the reader of the veracity of the Federal Reserve's observations, illuminate their value for historical research, and elucidate the information available in the database, so that readers may effectively employ it in their own research.

\section{$\underline{\text { Location, Organization, and Citation }}$}

From 1929 through 1933, the Federal Reserve Board of Governors collected information on bank changes on three forms. Form St. 6386a reported bank consolidates. Form St. 6386b reported bank suspensions. Form St. 6386c reported all other bank changes. Facsimiles of the forms appear below. The surviving forms may be found in the National Archives, Record Group 82, Federal Reserve Central Subject File, file number 434.-1, "Bank Changes 1921-1954 Districts 1929-1954 - Consolidations, Suspensions and Organizations-St. 6386 a,b,c, (By States) 1930-1933.” The forms are filed alphabetically by state, name of town or city, and name of bank. Multiple entries for individual banks appear in chronological order. To avoid repeated, lengthy citations in the body of the essay and this appendix, after quotations from the archival data, the information required to locate the form (i.e. name of state, town, bank) is indicated in brackets.

Defining and Classifying Changes in Bank Status: Origins and Procedures of the Process

During the 1920s, the Federal Reserve Board of Governors embarked on an ambitious project: the creation of standard statistical reports for all banks operating in the United States, both members of the Federal Reserve System and nonmembers, national and state, incorporated and private. In August 1925, the Board began collecting information on the causes of bank suspensions. The Division of Bank Operations introduced Form X-4401, "Notification of Bank Suspension or Insolvency,” and Form X-4402, "Notification of Termination of Insolvency or Suspension.” The forms remained in use for four years. During that period, the Board of Governors strove to improve the accuracy of the information that they collected. The process was interactive and ongoing. The Board circulated forms to agents around the country and asked them to suggest improvements. They solicited comments from bureaucrats, bankers, examiners, and academics. They amended the forms to make them more concise and complete. Correspondence between the Board of Governors and the Federal Reserve district banks announced up-and-coming modifications and important decisions concerning the coding of ambiguous cases. A series of memos defined key terms and explained how to fill out the forms.

Analysts strove to standardize the definitions of the words with which they worked. Standardization was important, because definitions of banking terms varied across time and jurisdictions. Each state-banking bureau published its own report and used terms as it saw fit. Explicit definitions seldom appeared. This lexical ambiguity caused confusion. Multiple definitions existed for frequently used terms. Many varied according to context. For example, the nine letters l-i-q-u-i-d-a-t-e referred in some circumstances to the sale of assets, in other circumstances to a change in a corporate charter, and at other times to the dissolution of a financial institution and its departure from the banking business. At the end of the 1920s, as the Federal 
F. R. Board

Form St. 6386a

November 1929
BANK CONSOLIDATIONS

(Include absorptions, mergers, etc.)

Effective data of consolidation

Federal Reserve District

\begin{tabular}{c|c|c|c|c|}
\hline Name and Location of Banks & $\begin{array}{c}\text { Member } \\
\text { or } \\
\text { nonmember }\end{array}$ & Capital & $\begin{array}{c}\text { Surplus } \\
\text { and } \\
\text { profits }\end{array}$ & $\begin{array}{c}\text { Loans } \\
\text { and } \\
\text { investments }\end{array}$ \\
\hline
\end{tabular}

(a) Banks entering into consolidation:

(b) New or consolidated bank:

Is the consolidated institution a newly chartered bank? ___. If not, give the name of the bank (before consolidation) under whose charter the consolidated institution is to operate:

Give the names of banks, if any, that were in financial difficulties at time of consolidation:

Disposition made of the head office of each bank entering into consolidation:

Did any of the banks entering into consolidation have branches? Were any of the banks affiliated with banking groups or chains?

(Report details on Forms St. 6386d and St. 6386e)

Terms of consolidation, if known, etc. 
F. R. Board

Form St. 6386b

November 1929

Date of suspension

Name and location of bank

\section{Loans and}

Capital \$

Investments \$
Federal Reserve District

Member or nonmember

Gross Deposits \$

Borrowings from Federal Reserve Bank \$ From other banks \$

Condition figures are as of

Closing directed by

Causes of suspension: Check in the appropriate column those of the following which apply, either as primary or contributing causes, amplifying the indicated causes with such supplementary data as may be available.

1. Slow, Doubtful or worthless paper

\begin{tabular}{|l|l|}
\hline Primary cause & Secondary cause \\
\hline
\end{tabular}

2. Failure of banking correspondent (Name of failed correspondent)

3. Failure of other large debtor (Name of failed debtor and connection with bank, if any)

4. Defalcation

5. Heavy withdrawals

6. Other causes (specify)

\section{)}

BANK SUSPENSIONS

$\longrightarrow$

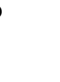


F. R. Board

Form St. 6386c

Nov. 1929
ORGANIZATIONS, LIQUIDATIONS, CONVERSIONS, AND OTHER CHANGES IN STATUS OF MEMBER AND NONMEMBER BANKS

Effective date of change

Federal Reserve District

Character of change

Name and location of

bank before change

Member or

nonmember

Member or

Name and location of

nonmember

bank after change

Surplus

Capital \$

and profits $\$$

Loans and

investments \$

Condition figures are as of

Is the above change in status final or merely preliminary to a further change, and if preliminary, what further change is contemplated?

Is the case of conversions and successions, were financial difficulties responsible to any extent for the change in status?

Remarks:

(In the case of suspended banks reopened for business, give the change in capital account, the assessment paid by stockholders, etc.) 
Reserves' lexicon approached its final form and its research staff assimilated the lessons that they had learned, the Board of Governors authorized a comprehensive revision of the panoply of forms used to gather information on the status of banks.

In 1929, the Board of Governors introduced the documents devised via that endeavor: the St. 6386

series of forms. Form St. 6386a reported bank consolidations. The Federal Reserve defined consolidation in a de facto rather than de jure sense.

A consolidation is the corporate union of two or more ongoing banks into one bank which continues under a single charter, either new or old. The term is used not in a legal or technical sense, but in an economic sense, the essential feature being that the business of two or more going banks becomes concentrated under one charter and one management. The method of effecting the consolidation, whether by purchase of assets, assumption of deposit liabilities, exchange of stock, or other procedure, varies with circumstances and is unessential for the present purpose. What is here described as a consolidation is frequently designated by the terms "merger," "absorption," "amalgamation," "combination," or "purchase," according to different points of view. It includes those cases where one bank absorbs another and turns it into a branch. It also includes those cases where a given bank is absorbed by two or more banks, which distribute its business among themselves. A consolidation is not a simple transaction like a conversion, a liquidation, a primary organization, etc., but is inevitable complicated by the fact that these other transactions are incidental to it. That is, a consolidation as often as not entails a voluntary liquidation and the issuance of a new charter; but these attendant circumstances should not obscure the important fact that a concentration of banking has been effected by the transaction as a whole (Goldenweiser et. al. 1931, pp. 87-88).

Form St. 6386a recorded these transactions and the attendant circumstances. Details included the name of the absorbing bank, the fate of offices and charter of the bank being absorbed, and whether the banks consolidated because they faced financial difficulties or in order to avoid suspension.

The latter information helped distinguish between the categories of consolidation and suspension. The distinction involved several simple rules. First, a bank that merged with another bank was classified as a consolidation if it was "not at any time closed to depositors, even though the reason for the consolidation or succession may have been financial difficulties encountered by the bank (Federal Reserve memo, November 18, 1929)." Second, a transaction was classified as a consolidation if the assets and liabilities of a weak bank were transferred to another bank, and then, the denuded bank suspended and surrendered its charter (Goldenweiser et. al. 1931, p. 88). Third, a transaction was classified as a terminal bank suspension if at the time of absorption or merger the bank had been closed for at least one business day.

Form St. 6386b reported bank suspensions. According to the Federal Reserve’s financial lexicon, a bank suspension occurred when payments were halted

to the public either temporarily or permanently by supervisory authorities or by the bank's board of directors on account of financial difficulties, regardless of whether or not the bank is ultimately classed as a suspension by the supervisory authorities (Federal Reserve memo, November 18, 1929)

and regardless of whether or not the depositors ultimately suffered losses. A suspension had to last overnight. A bank that closed its doors in the morning and reopened them in the afternoon did not fit into the classification. A suspension had to include the cessation of normal banking business. A bank that slowed withdrawals by holding depositors to the agreements that they signed when opening accounts and requiring them to provide 30,60, or 90 days notice of savings withdrawals did not fit into the classification. A bank which, without actually closing, obtained agreements from depositors to waive a portion of their deposits or to defer the withdrawal of a portion of their deposits was not classified as a suspension. A bank that closed 
during a special holiday declared by civil authorities and remained closed only during such holiday or part thereof was not classified as a suspension.

Form St. 6386c reported changes in the status of financial institutions, including voluntary liquidations and the reopening of suspended banks. A voluntary liquidation occurred when a bank's directors paid off all depositors and creditors in full, sold the remaining assets, distributed proceeds to stockholders, annulled the bank's charter, and abandoned the banking business. Some voluntary liquidations were orderly affairs arranged months in advance. Others resembled suspensions. A sudden shock, such as the death of the founder, forced a bank to close its doors, and the discouraged board of directors decided to repay depositors rather than attempt to reopen the institution. The latter case was classified as a voluntary liquidation, rather than a suspension, as long as the winding up of the bank's business did not require the intervention of regulators or courts, and as long as the owners of the bank could repay all creditors the full value of their claims.

A reopening occurred when a suspended bank resumed operations. A bank could resume operations voluntarily at any time until regulators used legal powers to take authority over the institution or the courts appointed a receiver to liquidate the bank. After either event, a bank could reopen only with the consent of judicial authorities. In certain circumstances, reopening also required the agreement of creditors such as depositors and stockholders. In many cases, reopenings entailed the reorganization of affairs. Depositors waived rights to portions of their deposits. Stockholders waived their original capital and paid assessments of up to $100 \%$ of the value of their stock. In most cases, these reorganizations appear to have been voluntary agreements among the interested parties, facilitated by banking authorities on some occasions and laws in some states.

A reopening could involve an array of incidental transactions, such as changes in the name, charter, capital stock, and legal status of a bank. As with consolidations, the entire package of transaction was recorded as a single event. Rules indicated how to handle confusing cases. For example,

A reopening consequent upon consolidation of two or more suspended banks should be classed as a single reopening. If a suspended national bank reopens as a State bank, however, or vice versa, the transaction must be accounted as a primary organization and not as a reopening (Federal Reserve memo, November 18, 1929).

Thus, if two banks suspended operations, merged a few days later in the morning, and reopened that afternoon, the Federal Reserve recorded two suspensions, one reopening, one liquidation, and no consolidations. The bank whose charter continued in use was listed as reopened. The bank whose charter lapsed was listed as liquidated. If two banks suspended operations, reopened a few days later in the morning, and merged that afternoon, however, the Federal Reserve recorded two suspensions, two reopenings, and one consolidation. If a national bank suspended operations, changed to a state charter, and then reopened for business with exactly the same staff, depositors, and borrowers, the Federal Reserve recorded one national bank suspension, one national bank liquidation, and the opening (i.e. primary organization) of a newly statechartered bank. If a similar national bank suspended operations, reopened for business, and then adopted a state charter, however, the Federal Reserve recorded one suspension, one reopening, and one conversion from national to state charter.

Completing forms St. 6386c and St. 6386a involved implementing algorithms to determine how to classify complex transactions. Completing the $6386 \mathrm{~b}$ form required additional knowledge, judgment, and effort. The 6386b form attributed bank suspensions to one or more of five common causes (definitions from Federal Reserve memo, November 5,1930$).{ }^{16}$ The first was slow, doubtful, or worthless paper. The term worthless paper indicated an asset with little or no value. The term doubtful paper meant an asset unlikely to yield book value. Examples included loans to businesses in financial difficulties and securities such as stocks

16 Note that a sixth option existed. Agents completing St. 6386b forms could check a box entitled "other cause" and add a description of the phenomenon. The form also contained space for written remarks. About one-third of all forms contained such additional and/or extended comments. 
and bonds which had depreciated since purchase. The term slow paper meant an asset likely to yield full value in time, but whose repayment lagged or that could not be converted to full cash value at short notice. An example was a loan to a profitable corporation with cash-flow problems struggled to make timely payments. The term structure prevented the bank from calling in the unpaid balance. Uncertainty over the value of the stream of payments prevented the bank from selling the loan at face value.

The second common cause of suspension was failure a banking correspondent. Correspondents were banks with ongoing relationships facilitated by deposits of funds. Services rendered by correspondents included extending lines of credit, clearing checks, absorbing exchange charges, redeeming coupons from bonds, conducting wire transfers, supplying coins and cash, and facilitating investments in stocks and bonds. A typical situation involved a small state bank outside a reserve city (called a country bank) that deposited funds in a large national bank in a reserve city (called a city bank) and received services in return. Such deposits often formed a large portion of country banks' legal reserves. In many cases, the suspension of the city bank precipitated the suspension of the country bank, because the latter lost its reserves and linkages to the wider financial system.

The third and fourth common causes of suspension were the failure of a large debtor and defalcation. Of particular interest were debtors with connections to the bank via overlapping ownership, interlocking directorates, or intermingled management. Defalcation was a monetary deficiency in the accounts of a bank due to fraud or breach of trust for which the management was legally liable. Embezzlement was a common example.

The fifth common cause of suspension was heavy withdrawals. Some banks experienced such large withdrawals that they could no longer continue operations. These deposit declines could be dramatic events in which multitudes of small-account holders lined up in the streets outside of banks hoping to empty their accounts. But, long queues of despondent depositors could be a symptom, rather than a cause, of a bank's demise. Significant deposit losses usually occurred before ordinary men and women lined up on the streets outside of their banks. Businesses, banks, and wealthy individuals possessed the ability to transfer funds quickly via wire or check to other financial institutions. They often also possessed better-than-average information about financial events and transferred large sums out of banks in weeks before ordinary individuals panicked over the safety of their savings or banks suspended payments on deposits. Researchers at the Federal Reserve called these events invisible runs.

The Board of Governors spent several years refining this checklist and teaching representatives how to complete the form. Instructions were straightforward. If acts for which management faced criminal liability precipitated the suspension of payments, check the box labeled defalcation. If the failure of a correspondent or debtor precipitated the suspension of payments, check the appropriate box and note the name of the institution or individual. If withdrawals reduced the liquidity of a bank to the point that it could not continue operations or forced the bank to sell assets at fire sale prices, and thus to choose between suspending payments or suffering insolvency, check the box for heavy withdrawals. If bad assets accumulated to such an extent that a bank could not continue operations, either because it could not maintain the necessary cash flow, because it could no longer absorb the losses, or because auditors determined it to be insolvent, check the box for slow, doubtful, and worthless paper. Place the check in the column labeled primary cause if that factor alone forced the bank to suspend operations. Place the check in the column labeled contributing cause if that factor aggravated or accelerated the bank's demise.

Agents often checked multiple boxes, indicating that multiple causes contributed to a bank's suspension. The most common combination was heavy withdrawals and slow, doubtful, and worthless paper. That should be no surprise. Withdrawals forced a bank to suspend payments only if the bank could not convert assets to cash quickly enough to cover claims against it. Bad assets would not force a bank out of business if it retained sufficient deposits and eventually covered its losses. Runs and frozen assets, in other words, could be flip sides of the same coin.

Differences did exist, however, between the asset and liability side of the balance sheet. Agents attempted to communicate these distinctions by marking primary and contributing causes in particular patterns. If the problems precipitating suspension arose on the asset side of a bank's balance sheet, agents checked slow, doubtful, or worthless paper as the primary cause and withdrawals as a contributing cause or 
not at all. Checking paper as the primary cause indicated that problems with the bank's assets necessitated suspension regardless of other factors. The banks' assets possessed little value. Collections had fallen far behind scheduled. The capital was impaired. The bank was or would soon be insolvent. Checking withdrawals as a contributing cause indicated that depositors' demands exacerbated the situation. Withdrawals could complicate asset problems in several ways. A run on a bank on the edge of insolvency might hasten its demise. Fears of runs might force a bank to hold large reserves of liquid assets, such as cash, rather than large portfolios of remunerative assets, such as loans, preventing the bank from earning profits and writing off bad debts. In an effort to satisfy depositors' demands, a bank might sell so many of its good assets that only bad assets remained, or a bank might borrow against so many of its better investments, that it could not earn enough profits to retire its substandard loans.

If the problems precipitating suspension arose on the liability side of the bank's balance sheet, agents checked heavy withdrawals as the primary cause and paper as a contributing cause or not at all. Checking withdrawals as the primary cause indicated that deposits declined to such an extent that the bank could not continue operations. Its reserves of cash were depleted. It could not longer convert assets to currency. It could not satisfy depositors' demands. Checking paper as the contributing cause indicated that the condition of the bank's assets exacerbated the situation. Doubtful and worthless assets could neither be sold nor rediscounted. Slow assets could not be converted to cash quickly enough to alleviate a run. Substandard assets of any kind reduced banks' liquidity and prevented them from converting resources to cash.

If problems arose equally on both sides of the balance sheet, agents checked both withdrawals and paper as primary causes. In this case, the bank's position was doubly difficult. Its assets appeared so problematic that insolvency approached, and its depositors withdrew so much of their savings that illiquidity loomed. Checking two primary causes indicated that either factor alone would have caused the closure of the bank.

\section{Data Sources and Cross-Validation}

The Board of Governors strove to gather information about causes of suspension from the man on the spot who knew the facts of the issue at hand. Annotations on the forms reveal these efforts. Comments on hundreds of forms indicate that the information agrees with the receiver's report or was taken "From receiver's report as of date of closing," a phrase often imprinted with an ink stamp. Federal Reserve agents often communicated directly with receivers, requesting additional information or inquiring about complex or unclear cases. Receivers' replies appear on many forms. For example, the receiver for Mayo’s Money Exchange Bank of San Antonio, Texas, stated "the primary cause of failure was due to investments of funds in stocks and bonds representing real estate investments.” The Central Bank and Trust Company of Chicago, Illinois, which was the liquidation trustee of the Mecca Bank of Mecca, Indiana, stated the bank should be classified as a voluntary liquidation because "all of the creditors will be paid off in full within a reasonable period.” A letter dated 6 October 1932 and written by F. E. J. Bower, the receiver for the First National Bank of Bradley Beach, New Jersey, described the "reorganization plan as follows: Creditors were to waive $40 \%$ of claims against the closed bank, total amounts of such waiver equal $90 \%$ of present liabilities. Old stock of bank (\$100 par) to be surrendered and then resold at \$25 per share in this way raising \$125,000.”

The Division of Bank Operations also consulted call reports and examination reports and communicated directly with bank examiners and banking departments. Examples abound. The examiner of the Central National Bank in Bartleaville, Oklahoma, which suspended on March 22, 1930, classified "\$235,000 of assets as worthless and \$164,000 as doubtful." The examiner of the First National Bank of Bixby, Oklahoma, which suspended on February 18, 1929, stated "the suspension of this bank is chargeable directly to top heavy and other ill-advised loans made during the period of inflation following the recent war, together with the incompetency of succeeding officers in the matter of enforcing any effective policy of collection over the following period of deflation.” On 28 February 1931, a letter from the Bank Commissioner of Connecticut stated 
the Central Fairfield Trust Company of Norwalk, now the Merchants Bank and Trust Company, resumed business on Friday, February 20, 1931. The name of the institution was changed by special act of the legislature. While the name has been changed, it is still the same corporation which has resumed business upon the discharge of the temporary receiver appointed by the courts.

In January 1930, a telegram from the Indiana State Banking Department explained the complicated series of transactions surrounding the suspension of the Argos State Bank of Argos, Indiana, and its reopening under a new charter. In March 1933, the Utah State Bank Commissioner reported that Gunnison Valley Bank of Gunnison, Utah, would reopen shortly. On 27 March 1930, an employee of the Division of Bank Operations with the initials M.F. called Mr. Gough of the Comptroller of Currency after “examination of agent's reports proved inadequate.” Mr. Gough explained that the myriad of transactions reported for the town of Bartow, Florida, pertained to the closure of a single institution, the Polk County National Bank, which unsuccessfully attempted to shed dubious assets, change its charter, and establish itself as a new bank under a different name in hopes of saving itself.

The Division of Bank Operations also contacted institutions and individuals with local knowledge of particular banks. Local courts provided access to liquidation records, names and addresses of court-appointed receivers, and opinions about suspended banks under their jurisdiction. Local postmasters provided another means to attain such information. For example, on 10 December 1930, a letter from the postmaster at Sandia, Texas, informed the Federal Reserve that W.T. Mumme, the private bank in the town, ceased operations and liquidated voluntarily.

For country banks, a good source of information was their banking correspondent. Correspondents in reserve cities held deposits of county-bank clients, provided clients with services such as check clearing and wire transfers, and monitored clients' financial health and creditworthiness. Correspondents frequently replied to inquiries concerning the closures of the clients. Many examples exist. The correspondent of Juan McKeyes and Company, a private bank in Lawton, Michigan, wrote that McKeyes suspended operations on May 9, 1932 due to the financial consequences of grape crop failures in the area, and reopened on June $2^{\text {nd }}$ of that year

after its depositors of their own volition had signed waiver agreements providing that no funds except such as are deposited after the bank reopened would be withdraw for a period of five years. Under the circumstances the court having jurisdiction over its affairs dismissed the receivership petition.

The Continental Illinois Bank and Trust Company, which was the correspondent of the Commercial Bank of Wapellow, Iowa, stated that the latter closed its doors on October 13, 1931, because the ...

bank unwisely expanded loans to care for needs of borrowers in communities where banks had suspended and found itself unable to meet shrinkage in its deposits due to unrest among its own customers.

The Valley National Bank of Des Moines, Iowa stated that its client, the Farmers and Merchants Bank of Scranton, Iowa, suspended operations primarily because it was "loaded with slow, doubtful, and worthless paper."

Banks provided information about their own conditions. Reopened banks answered inquiries about the cause of their temporary suspensions and the conditions under which they reopened. Banks entering into voluntary liquidation released public statements explaining how and why. Even the management of failed banks provided information in instances when Federal Reserve agents contacted them directly. For example, in the fall of 1930, Harry M. Wilcox, the President of the Citizens Bank of North Adams, Michigan, replied to an inquiry about the cause of his bank's suspension by stating "general business depression and decline in land value caused the bank to close its doors." Federal Reserve agents could gather this information because 
they possessed the legal authority to compel truthful testimony. The law required bankers to answer their inquiries. Untruthful respondents could be prosecuted for perjury. Federal Reserve agents seeking answers from reticent witnesses could ask the Office of the Comptroller of Currency (OCC) for assistance. OCC examiners could compel a response, since they possessed investigative powers identical to secret service agents.

Federal Reserve agents consulted the publications of the state banking departments. ${ }^{17}$ Most banking departments published annual reports. A few published biennially. Many banking departments also published summaries of bank changes in the interim. Periodicity varied across states. Indiana published a monthly bulletin. The New York State Banking Department published a weekly bulletin with detailed descriptions of the causes of each state bank suspension. The New York Superintendent of Banks also released an announcement at the time of each bank suspension, stating the reasons why it was "deemed unsafe and inexpedient to permit the institution to continue in business.” The Federal Reserve banks also compiled monthly summaries of bank changes, which they forwarded to the Board's Division of Bank Operations.

Federal Reserve agents also consulted an array of business periodicals and popular dailies. Citations to the following appear on the 6386 forms:

- Commercial and Financial Chronicle
- New Yors'Monthly
- New York Sun
- Polk’s Bankers Encyclopedia
- Rand McNally Bankers Directory
- Reports of R.G. Dunn \& Company

Numerous newspapers from locales around the United States were also cited, but the typists who transcribed the newspaper clippings merely stated that their source was a 'local newspaper' without additional bibliographic details.

Each of these sources possessed its own strength. Federal Reserve officers had direct and continuous contact with the management of member banks and the ability to comment credibly on their competency. Correspondents could also provide vivid and valuable testimony on this issue. Correspondents had ongoing relationships with the management of client banks, and tracked the quality of their clients' portfolios in case decisions had to be made about the extension of credit. Call, examiners', and receivers' reports yielded financial data including the kind, quality, and quantity of assets possessed by a bank on the date of suspension and the patterns of deposit inflows and outflows before that date. Examiners of all national and most state banks classified assets according to the categories good, slow, doubtful, and worthless, which the Federal Reserve used on its suspension forms. Receivers of national and state banks also listed assets and estimated values. Discussions with examiners, receivers, correspondents, and bankers provided expert opinions about phenomena that they observed, often over a period of years. Particularly useful are their opinions about the quality of the management and the importance of correspondent linkages. Newspapers provided detailed descriptions of events that interested their readers, such as defalcations and bank runs, and on important financial events in their hometowns, such as the closing and reopening of local banks. Much of the information provided by these sources could come from nowhere else.

The Federal Reserve Board incorporated all of this information into the 6386 forms by creating a nationwide reporting network. The law required member banks to report changes in status to their local Federal Reserve Bank. Similar regulations required national banks to report such information to the Office of the Comptroller of the Currency. Federal Reserve agents at district and branch banks completed initial drafts of the forms from information at their disposal and forwarded the forms to the Board of Governors in

17 Katherine Tunis, head of the research library of the Board of Governors, reports that the Board's library retained copies of all publications from the state banking departments until the late 1970s, when to conserve shelf space, the library sent all of these publications to the libraries of the Federal Reserve district banks. 
Washington, where the Division of Bank Operations checked the information against available sources (including copies of the materials submitted to the OCC and routinely forwarded to the Federal Reserve), sorted and tabulated the forms, compiled aggregate statistics, and disseminated the results. Nonmember banks reported to state authorities, which cooperated in the Federal Reserve's data-collection endeavors by forwarding the relevant information. The Federal Reserve cultivated contacts with state agencies, and during the Depression, subsidized the salaries of state employees who worked part time on Board businesses.

In complicated, unclear, and unresolved cases, the Division requested additional information and researched the events in greater depth. The definitive determination of the cause of a bank suspension often took several months. The archives contain preliminary, in-process, and final reports for many banks. These duplicates accumulated as agents incorporated additional information into their analysis and updated their conclusions. Information flowed to the Division of Bank Operations as institutions and individuals replied to Federal Reserve requests for information. In several cases, the materials collected by the Division, such as examiners' reports, telegrams from receivers, press clippings, etcetera, remain clipped to the 6386 forms, although routine procedure appears to have been to discard the source material after reaching a definitive determination of the cause of a bank's failure

The Board's efforts continued throughout the Depression. After the national banking holiday, the Board joined forces with the Office of the Comptroller of Currency and the Federal Deposit Insurance Corporation. With funding from the Works Project Administration, this regulatory triumvirate strove to construct a data base containing information from all banks operating in the United States since 1929. As part of the process, the Board of Governors rechecked the 6386 forms against the records of the state banking bureaus, the OCC, and the Rand McNally and Polk corporations. The Board published the initial results of this reconciliation in the Federal Reserve Bulletin for September, 1937. Further publications were planned, but the project lapsed as the Board allocated resources towards other projects. 


\section{Bibliography}

Bernanke, B. S. "Nonmonetary Effects of the Financial Crisis in the Propagation of the Great Depression.” American Economic Review, June 1983, (73), pp. 257-276.

Board of Governors of the Federal Reserve System. 1929. "Memorandum Regarding Preparation of Reports of Changes in Status of Member and Nonmember Banks,” Memo: November 18, 1929. National Archives, Record Group 82, Federal Reserve Central Subject File, 421.113.

1930. Committee on Branch, Group and Chain Banking, "Bank Changes - Definitions of Terms," Memo: November 5, 1930. National Archives, Record Group 82, Federal Reserve Central Subject File, 421.113-1.

1931. Committee on Branch, Group and Chain Banking. "Comments Regarding Preparation of Form F.” 23 November 1931. National Archives, Record Group 82, Federal Reserve Central Subject File, 421.113-1, Forms and Instructions.

1937. "Bank Suspensions in the United States.” Federal Reserve Bulletin. Washington, D.C.: Board of Governors of the Federal Reserve System. September, 1937.

----- Banking and Monetary Statistics, 1914-1941. Washington, D.C.: Federal Reserve System, 1943.

----- All Bank Statistics, 1896-1955. Washington, D.C.: Federal Reserve System, 1959.

Calomiris, Charles W. and Joseph R. Mason. "Contagion and Bank Failures During The Great Depression: The June 1932 Chicago Banking Panic.” American Economic Review, December 1997, 87(5), pp. 863883.

----- “Fundamentals, Panics, and Bank Distress During the Depression.” American Economic Review, December 2003, 93(5): pp. 1615-1646.

Carlson, Mark. “Are Branch Banks Better Survivors? Evidence from the Depression Era.” Economic Inquiry, January 2004, (42), pp. 111-126

Christiano, Lawrence J., Roberto Motto, and Massimo Rostagno. "The Great Depression and the FriedmanSchwartz hypothesis,” Working Paper 0318, Federal Reserve Bank of Cleveland. 2004.

Diamond, Douglas W. and Philip H. Dybvig. “Bank Runs, Deposit Insurance, \& Liquidity,” Journal of Political Economy, 1983, Vol. 91, pp. 401-419.

Eichengreen, Barry. Golden Fetters. New York: Oxford University Press, 1992.

Friedman, Milton and Schwartz, Anna J. 1971. A Monetary History of the United States, 1867-1960. Princeton: Princeton University Press.

Goldenweiser, E. A., et al. 1931. Bank Suspensions in the United States, 1892-1931. Volume 4. Material prepared for the information of the Federal Reserve System by the Federal Reserve Committee on Branch, Group, and Chain Banking.

Hamilton, David. “The Causes of the Banking Panic of 1930, Another View.” Journal of Southern History November 1985, (51), pp. 581-608. 
Hori, Masahiro. New evidence on the causes and propagation of the great depression. Dissertation. Ph.D. in Economics. University of California, Berkeley, May 1996.

Kennedy, Susan Estabrook. The Banking Crisis of 1933. Lexington, KY: University Press of Kentucky, 1973.

Lucia, Joseph. 1985. “The Failure of the Bank of the United States: A Reappraisal.” Explorations in Economic History 22 (October): 402-16.

McFerrin, James B. 1939. Caldwell and Company. Chapel Hill: University of North Carolina Press.

Meltzer, Allan H. "Monetary and Other Explanations for the Start of the Great Depression.” Journal of Monetary Economics 2 (1976): 455-72.

----- A History of the Federal Reserve, Volume 1, 1913-1951. Chicago: University of Chicago Press, 2003.

Mitchener, Kris James. 2004. Bank Supervision, Regulation, and Instability during the Great Depression. NBER Working Paper 10475. May 2004.

Gary Richardson. "The Records of the Federal Reserve Board of Governors in the National Archives of the United States.” Financial History Review (forthcoming June 2006).

Richardson, Gary and William Troost. "Monetary Intervention Mitigated Banking Panics During the Great Depression: Quasi-Experimental Evidence from the Federal Reserve Border in Mississippi, 1929 to 1933..” UC Irvine Mimeo, 2005.

Romer, Christina. “The Nation in Depression.” The Journal of Economic Perspectives. Vol 7, No. 2 (Spring, 1993), pp. 19-39.

Temin, Peter. Did Monetary Forces Cause the Great Depression? New York: W.W. Norton, 1976.

---- Lessons from the Great Depression. Cambridge, MA: MIT Press, 1989.

United States, Bureau of the Census. Historical statistics of the United States, colonial times to 1970. Bicentennial Edition. Washington: U.S. Dept. of Commerce, U.S. Govt. Print. Off., 1975

Wheelock, David. "Member Bank Borrowing and the Fed's Contractionary Monetary Policy During the Great Depression.” Journal of Money, Credit and Banking November 1990, (22) pp. 409-426.

White, Eugene. 1984. “A Reinterpretation of the Banking Crisis of 1930.” Journal of Economic History 44 (March): 119-38.

Wicker, Elmus. 1980. “A Reconsideration of the Causes of the Banking Panic of 1930.” Journal of Economic History 40 (September): 571-83.

----- $\quad$ 1996. The Banking Panics of the Great Depression. Cambridge: Cambridge University Press, 1996.

Young, R. A. "Memorandum Regarding Preparation of Reports of Changes in Status of Member and Nonmember Banks.” Memo: November 18, 1929. National Archives, Record Group 82, Federal Reserve Central Subject File, 421.3, Group and Chain Banking (1924-1929). 